\title{
Kernos
}

Revue internationale et pluridisciplinaire de religion grecque antique

$21 \mid 2008$

Varia

\section{The Dynamics of Ritual Space in the Hellenistic and Roman East}

Joannis Mylonopoulos

\section{(2) OpenEdition \\ Journals}

\section{Electronic version}

URL: https://journals.openedition.org/kernos/1601

DOI: 10.4000/kernos.1601

ISSN: 2034-7871

\section{Publisher}

Centre international d'étude de la religion grecque antique

\section{Printed version}

Date of publication: 1 January 2008

Number of pages: 49-79

ISSN: 0776-3824

\section{Electronic reference}

Joannis Mylonopoulos, "The Dynamics of Ritual Space in the Hellenistic and Roman East", Kernos

[Online], 21 | 2008, Online since 01 October 2011, connection on 24 August 2022. URL: http:// journals.openedition.org/kernos/1601 ; DOI: https://doi.org/10.4000/kernos.1601

All rights reserved 


\title{
The Dynamics of Ritual Space in the Hellenistic and Roman East
}

\begin{abstract}
Based on the archaeological data, the literary evidence, and the epigraphic sources, the article offers an overview of the strong interrelation between the dynamic changes in rituals and the subsequent architectural and structural adjustments of their space of performance. Violent interaction, social transformation, peaceful cross-cultural communication, the migration of new populations, the introduction of new cults, the mobility of ethnic and religious groups, ideological and political factors, and rivalry between cult places are some of the parameters that need to be taken into account, when studying the interdependence between ritual and space. Chronologically, the focus lies mainly on the Hellenistic and Roman Imperial periods, but a few selected examples from the preceding periods shall complete the picture of this complex phenomenon.
\end{abstract}

Résumé : Cet article, fondé sur les données archéologiques, les témoignages littéraires et les sources épigraphiques, propose un panorama des relations étroites qui se nouent entre la dynamique des changements dans les rituels et les ajustements architecturaux et structurels qui en résultent dans l'espace de leur accomplissement. Pour étudier l'interdépendance entre rituel et espace, plusieurs paramètres doivent être pris en compte : les interactions violentes, les transformations sociales, la communication interculturelle pacifique, la migration de populations nouvelles, l'introduction de nouveaux cultes, la mobilité des groupes ethniques et religieux. L'arc chronologique de cette investigation s'étend de la période hellénistique à l'empire romain, mais quelques exemples tirés des périodes antérieures permettront de compléter le tableau de ce phénomène complexe.

\section{Introduction}

Around 167 BC, Antiochos IV attempted to violently impose a dramatic change in religious attitude and practices upon Judaea. The accounts in the first and second books of the Maccabees inform us that the Seleucid king had issued a decree throughout his empire, according to which all his subjects were to

* I am grateful to Barbara Borg, Angelos Chaniotis, and Alexander Herda for many useful discussions and suggestions. An earlier version of this paper was presented at the conference "Epigraphy and Beyond: Cultural and Linguistic Change in the Near East from Hellenism to Islam" organised by the Hebrew University of Jerusalem in 2003. The paper greatly profited from the critical remarks of the other participants, and especially from the discussions I had with Hannah Cotton and Nicole Belayche. I am very much obliged to cand. phil. Elisabeth Begemann for improving the English text. The views presented in this article emerged within the fruitful scholarly context of the interdisciplinary project "Ritualdynamik: Soziokulturelle Prozesse in historischer und kulturvergleichender Perspective" at the University of Heidelberg. 
become one people and abandon their ancestral laws and religion. In Judaea "ways and customs foreign to the country were to be introduced. Burnt offerings, sacrifices, and libations in the temple were forbidden: Sabbaths and feast-days were to be profaned [...]. Altars, idols, and sacred precincts were to be established swine and other unclean animals to be offered in sacrifice [...]. The penalty for disobedience was death". ${ }^{1}$ Apparently, the profanation of the existing religious traditions and the establishment of a different sacrificial practice fundamentally opposed to the Jewish laws of religious purity combined with newly founded sacred places was not enough, since the central sanctuary of Judaism, the temple in Jerusalem, experienced alterations regarding both the architectural setting for the ritual practices at the altar and, more importantly, its overall dedication: "On the fifteenth day of the month Kislev in the year 145 [= $167 \mathrm{BC}]$, 'the abomination of desolation' was set up on the altar [...]. On the twenty-fifth day of the month they offered sacrifice on the pagan altar, which was on top of the altar of the Lord."'2 Furthermore, the temple at Jerusalem was to be re-dedicated to the Olympian Zeus. ${ }^{3}$

Such an example of ritual dynamics born out of and based on enforcement can demonstrate how important sacred space and its modification were in order to suit the performative 'backstage' to new or changed rituals. ${ }^{4}$ And yet, rituals often present and are represented in scholarly publications as an aspect of worship that seems to be least related to geography, physical environment and landscape. Nevertheless, sacred space in a more abstract perception of the term

11 Maccabees I, 41-50 (all translations from The New English Bible With the Apocrypha, Oxford/

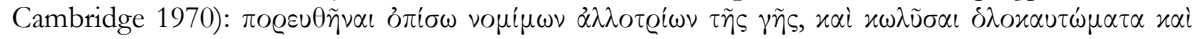

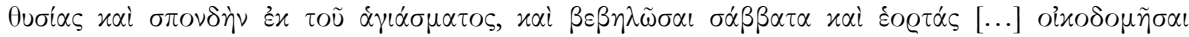

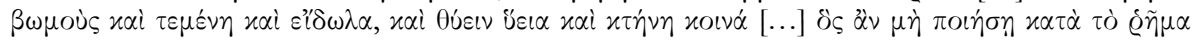

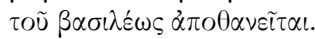

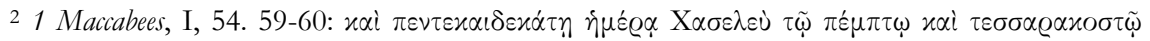

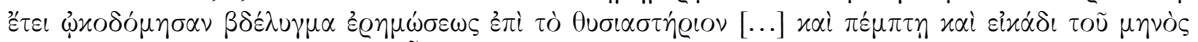

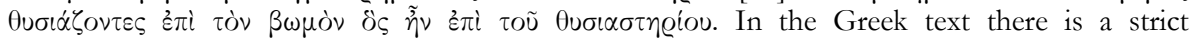
terminological differentiation between the pagan altar ( $\beta \omega \mu$ ós) and the altar of the temple

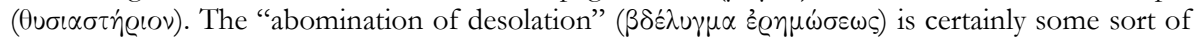
a cult statue, of. Th. FISCHER, Seleukiden und Makkabäer, Bochum, 1980, p. 35-37. While the first book of the Maccabees does not specify the exact form of sacrifice at this altar (the reference to the sacrifices of swines is related to all altars in Judaea), Flavius Josephus, Antiquitates Iudaicae XII,

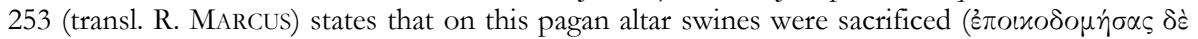

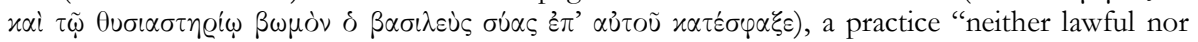
native to the religion of the Jews."

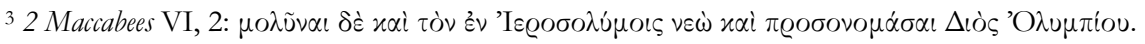
At the same time the sanctuary on Mount Gerizim was to be dedicated to Zeus Xenios.

4 A. Chaniotis, "Ritual Dynamics in the Eastern Mediterranean: Case Studies in Ancient Greece and Asia Minor", in W.V. HARris (ed.), Rethinking the Mediterranean, Oxford, 2005, p. 150 uses the altar in the temple in Jerusalem as an illustrative example for the opposition between the continuous use of a sacred space and the continuity in ritual, thus, he does not take into account the importance of the architectural changes in the direct vicinity of the altar aiming at the adjustment of the sacred space to the new sacrificial ritual. 
acquired a profound significance, whenever single rituals or entire cults were peacefully transferred into or violently imposed upon a different cultural and sometimes religious context. ${ }^{5}$ Some of the factors that generated a transfer of rituals were for example considerable movements of population in form of invasion, migration or colonization, the settlement of small groups of foreigners such as merchants, soldiers or exiles, the religious initiatives of a central administrative power, and the missionary activity of individuals or organized groups. ${ }^{6}$ Rivalries between cities or sanctuaries could also lead to transformations of sacred space, but sometimes such remodellings mainly aimed at an increase of pomp, and are not closely connected to the transfer of ritual practices. ${ }^{7}$ The numerous foundations of sanctuaries for the so-called

5 R. LANGER et al., "Transfer of Ritual", Journal of Ritual Studies 20.1 (2006), p. 1-10. The destruction of sacred spaces and their subsequent elevation to symbols demonstrates also their enormous importance, e.g. the destruction of the second Jerusalem temple and its transformation into an eschatological symbol, or the destruction of the Greek temples during the Persian wars (I do not intend to discuss here the issue of the historicity of this passage in the so-called oath of Plataiai).

${ }^{6}$ Chaniotis, l.c. (n. 4), p. 146-149. Very interesting cases of charismatic individuals transferring cults or introducing new ones are Apollonios, a priest from Memphis who introduced the cult of Sarapis to Delos in the first half of the third century BC (H. EngELmanN, The Delian Aretalogy of Sarapis, Leiden, 1975 [EPRO, 44]), and Alexander of Abonou Teichos, who 'invented' the cult of Glykon Neos Asklepios, based on elements borrowed from mystery, oracular and healing cults (A. CHANIOTIS, "Old Wine in a New Skin: Tradition and Innovation in the Cult Foundation of Alexander of Abonouteichos", in E. DABROWA (ed.), Tradition and Innovation in the Ancient World, Krokow, 2002 [Electrum, 6], p. 67-85; id., "Wie (er)findet man Rituale für einen neuen Kult? Recycling von Ritualen - das Erfolgsrezept Alexanders von Abounouteichos", Forum Ritualdynamik, Nr. 9, November 2004 [www.ub.uni-heidelberg.de/archiv/5103]). Already the Hettites seem to have written down and collected detailed instructions for ritual practices from various areas of Asia Minor, while ritual experts from these places must have been working for the Hettite administration and the royal house (the names of the ritual experts show that they came from Ankulla, Hurma, Arzawa, and Kizzuwatna), of. D. BAWANYPECK, Die Rituale der Auguren, Heidelberg, 2005, p. 241-264 on ritual instructions from the second half of the thirteenth century found in Hattusa, but originating from Arzawa (most probably the area around Ephesos).

7 W. Held, Das Heiligtum der Athena in Milet, Mainz, 2000 (Milesische Forschungen, 2), p. 85-88 explains, for example, the erection of the Milesian temple of Athena on a large podium as a possible reaction to the impressive archaic temples of Myus. Even if we accept Held's imaginative assumption, the construction of the podium in Miletos had an aesthetical and not a ritual background. More complicated is, however, the situation as regards the Panhellenic sanctuaries in Isthmia and Nemea: One of the most distinctive features of the sanctuary at Isthmia is the extremely long altar, erected in the seventh century and enlarged to a length of $40 \mathrm{~m}$ during the fifth century; the closest parallel is the long altar at the Nemean sanctuary, which had a similar development, since it was erected in the sixth and enlarged to a length of $41 \mathrm{~m}$ in the fourth century. Despite the plausible hypothesis, that Nemea took Isthmia as a model, it cannot be determined whether this adaptation of an architectural detail originated in aesthetic or ritual

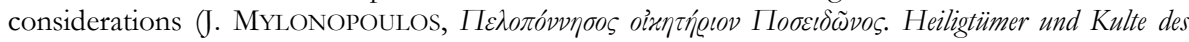
Poseidon auf der Peloponnes, Liège, 2003 [Kernos, Suppl. 13], p. 166-168). Since this 'interaction' between the two Panhellenic sanctuaries is related to a central element of cult activity (the altar), I am tempted to assume that in Isthmia and Nemea we do not have a case of merely a transmission of aesthetics, but also of ritual practices - at least in the level of performance. The physical 
Oriental and Egyptian cults ${ }^{8}$ and the establishment of dependencies of the Epidaurian cult of Asklepios 9 are probably the best-known and most illustrative examples for the transfer of entirely new, alien ritual forms in the context of acculturation processes (Oriental, Egyptian cults) and the dissemination of traditional cults within their own cultural settings (Asklepios).

The stronger presence of specific architectural forms, especially in the Hellenistic and Roman Imperial periods, most probably reflects changes in the performative aspects of cults. The countless porticos, which decisively shaped the architectural image of sanctuaries and cities in this period, best illustrate an intensification of performance. Even in rain, worshippers standing in a portico could still observe a procession or sacrifice and participate at least in a passive way in the religious action. ${ }^{10}$ At the same time, porticos more than any other architectural form created a monumental visual frame either leading the attention of the visitor directly to, or surrounding the very centre of the sanctuary (temple and altar). Innumerous Greek sanctuaries are visually shaped by stoas. The Asklepieion on Kos and the sanctuary of Athana on the acropolis of Lindos certainly belong to the most impressive examples. Sanctuaries like the one at Mamurt Kale or the sanctuary of Artemis Leukophryene in Magnesia on the Maeander also demonstrate how stoas can magnify the impression of sacred space. Dodona and Delos are good cases for time-honoured sanctuaries, which receive a higher spatial accentuation through the erection of stoas. The Asklepieion of Messene, the sanctuary of Zeus at Megalopolis, and again Dodona exemplify the function of stoas as impressive barriers that create a more intimate sacred space around the temple. Delphi, on the other hand, is indeed an interesting exception, since apart from the stoa of the Athenians and partly the one of Attallos no other stoa inside the temenos is really worth mentioning. Nevertheless, for visitors coming from the south the stoa of the Aetolians, the temple of Apollon, and the Attalid stoa must have created an

appearance of the Nemean temenos during the sixth century BC, strongly reminiscent of the Olympian altis, has been interpreted by C. Morgan, "Debating Patronage: The Cases of Argos and Corinth", in S. Hornblower, C. Morgan (eds.), Pindar's Poetry, Patrons, and Festivals. From Archaic Greece to the Roman Empire, Oxford 2007, p. 257-259 as a conscious attempt to legitimise the "parvenu in the crown cycle" by reference to Olympia.

8 The literature on this subject is vast. See more recently: A. Hoffmann (ed.), Ägyptische Kulte und ibre Heiligtümer im Osten des römischen Reiches, Byzas 1, Istanbul 2005 (with a strong archaeological approach); C. BONNET et al. (eds.), Religions orientales - nouvelles perspectives, Stuttgart 2006, and the papers collected in Archiv für Religionsgeschichte 8 (2006), p. 151-272, originating in a conference under the title "Les « religions orientales » dans le monde grec et romain" held at the Villa Vigoni in 2005 .

9 J. Riethmüller, Asklepios. Heiligtümer und Kulte, Heidelberg, 2005, passim.

10 D. KNIBBE, "Private Evergetism in the Service of the City-Goddess: The Most Wealthy Ephesian Family of the second Century CE Supports Artemis in her Struggle Against the Decline of her Cult after the Meteorological Catastrophe of 186 CE”, MedAnt 5.1 (2002), p. 49-62, attributes the roofing of the processional way to the Artemision in the late second century AD to climatic changes and the need to shelter the worshippers from heavy rainfalls. 
interesting visual axis of columns marking the very centre of the sanctuary. The numerous donations of edifices by Hellenistic rulers and Roman emperors are a manifestation of the increased instrumentalisation of religion. ${ }^{11}$ The foundation of new festivals or the extension of old ones required adequate facilities, which naturally also changed the religious topography of an already existing sacred place. All these aspects, here only epigrammatically listed, demonstrate the intensity of the interaction between cults or rituals and their architectural setting.

For a full understanding of the aforementioned phenomenon one needs a combined study of archaeological data, the epigraphic material and the literary sources, since the scarcity of information that explicitly refers to architectural changes due to ritual transfer or transformations often presents an unsurmountable obstacle. Being aware of these uncertainties, in this article I shall attempt to give a brief overview of the dynamic modification or creation of sacred space most likely connected to the transmission or foundation of new cults mainly during the Hellenistic and Roman Imperial periods, using some cases studies from Asia Minor, the Near East, and Greece. The majority of the examples selected also exemplify cross-cultural interaction in different degrees of intensity.

\section{Changed rituals - transformed places}

A remodelling of space due to ritual changes can already be assumed for Minoan Crete. Apparently, ritual dances played an important role in the religious life of the island. The old palace of Knossos, for example, had at its northwest side an open space, some sort of courtyard. ${ }^{12}$ During the New Palace

11 For dedications of Hellenistic rulers at Greek sanctuaries see B. SCHMIDT-DounAS, Geschenke erbalten die Freundschaft. Politik und Selbstdarstellung im Spiegel der Monumente, Berlin, 2000. It is interesting that stoas are a particularly popular type of dedication. There seems to be an apparent shift from the dedication of temples (extremely popular among archaic tyrants) towards stoas (both in sanctuaries and in public spaces such as the agora). Herodes Atticus is perhaps one of the best examples for a private individual who changed sacred space through his dedications and donations, of. M. GALLI, Die Lebenswelt eines Sophisten. Untersuchungen zu den Bauten und Stiftungen des Herodes Atticus, Mainz, 2002, p. 207-250.

12 N. Marinatos, "Public Festivals in the West Courts of the Palaces", in R. HägG, N. Marinatos (eds.), The Function of the Minoan Palaces. Proceedings of the Fourth International Symposium at the Swedish Institute in Athens, 10-16 June, 1984, Stockholm, 1987, p. 135-142. Marinatos reconstructs, however, harvest festivals taking place in this area without any major changes before and after the remodelling of the palace's west facade and assumes that the architectural changes were due to an increasing trend towards ritualisation and pomp. Recently, D. Panagiotopoulos, "Der minoische 'Hof als Kulisse zeremonieller Handlung", in J. Maran (ed.), Constructing Power. Architecture, Ideology, and Social Practice, Hamburg, 2006, p. 35 f. convincingly argued that one of the most important architectural features of the West courtyard were besides the staircases the elevated slab-built causeways, which he identified as part of a processional way between the so-called Little Palace and the west courtyard of the palace. 
period, this courtyard was changed architecturally into a theatral area by means of two monumental staircases. Here, most probably ritual dances and other performances took place, while people standing on the steps could watch. Fragments of a wall painting (known as the Sacred Grove and Dance Fresco), found during the British excavations in Knossos, depict such a ritual act in a very similar architectural context. ${ }^{13}$

The Spartan Artemision allows with a certain degree of doubt to interconnect modifications of the religious topography of a cult place to dynamic changes in ritual activities. In the second century AD Pausanias visited Sparta and heard of a curious ritual at the famous sanctuary of Artemis Orthia: "The Spartan Limnatians, the Cynosurians, and the people of Mesoa and Pitane, while sacrificing to Artemis, fell to quarreling, which led also to bloodshed many were killed at the altar and the rest died of disease. Whereat an oracle was delivered to them, that they should stain the altar with human blood. He used to be sacrificed upon whomever the lot fell, but Lycurgus changed the custom to a scourging of the lads, and so in this way the altar is stained with human blood. By them stands the priestess, holding the wooden image. Now it is small and light, but if ever the scourgers spare the lash because of a lad's beauty or high rank, then at once the priestess finds the image grow so heavy that she can hardly carry it."14 Pausanias is apparently describing some kind of a rite de passage and offers an explanation for the primary form of the ritual (a human sacrifice) dictated by the divine will expressed through an oracle in immemorial times, and its modification for unknown reasons by Lycurgus: In a few sentences, the reader is informed about the transformation of a ritual act (perhaps some sort of a scapegoat ritual) - imposed on the Spartans by the gods - into a rite de passage conceived as an alternative to human sacrifice by a powerful and wise person without any apparent divine interference. No one but Artemis herself,

13 D. Panagiotopoulos, "Das minoische Stierspringen. Zur Performanz und Darstellung eines altägäischen Rituals", in J. Mylonopoulos, H. Roeder (eds.), Archäologie und Ritual. Auf der Suche nach der rituellen Handlung in den antiken Kulturen Ägyptens and Griechenlands, Vienna, 2006, p. 131 speculates that the dancing women are not the actual centre of the performance. According to Panagiotopoulos' reconstruction the dance is just an element accompanying the main theme of a bull leaping or boxing scene, which, however, is not preserved. In my view, the ritual dance should be understood as one of the central visual elements of this fresco.

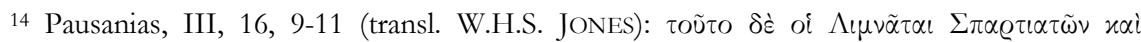

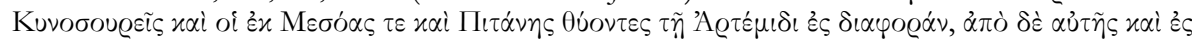

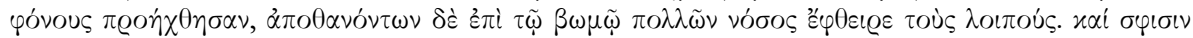

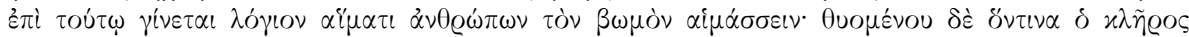

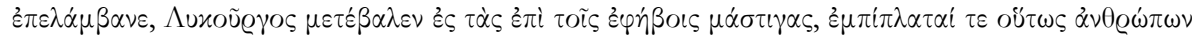

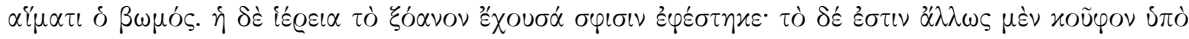

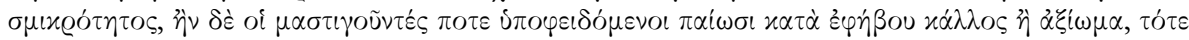

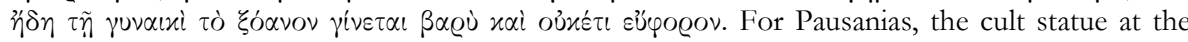
Spartan sanctuary of Artemis Orthia is certainly the one from the land of the Taurians and its

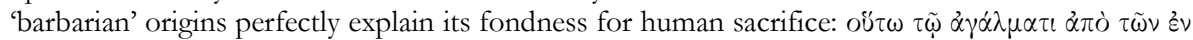

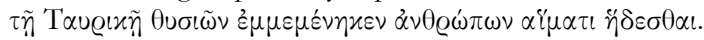


represented by her cult statue, oversees in a miraculous way the correct realisation of the ritual act.

Fig. 1

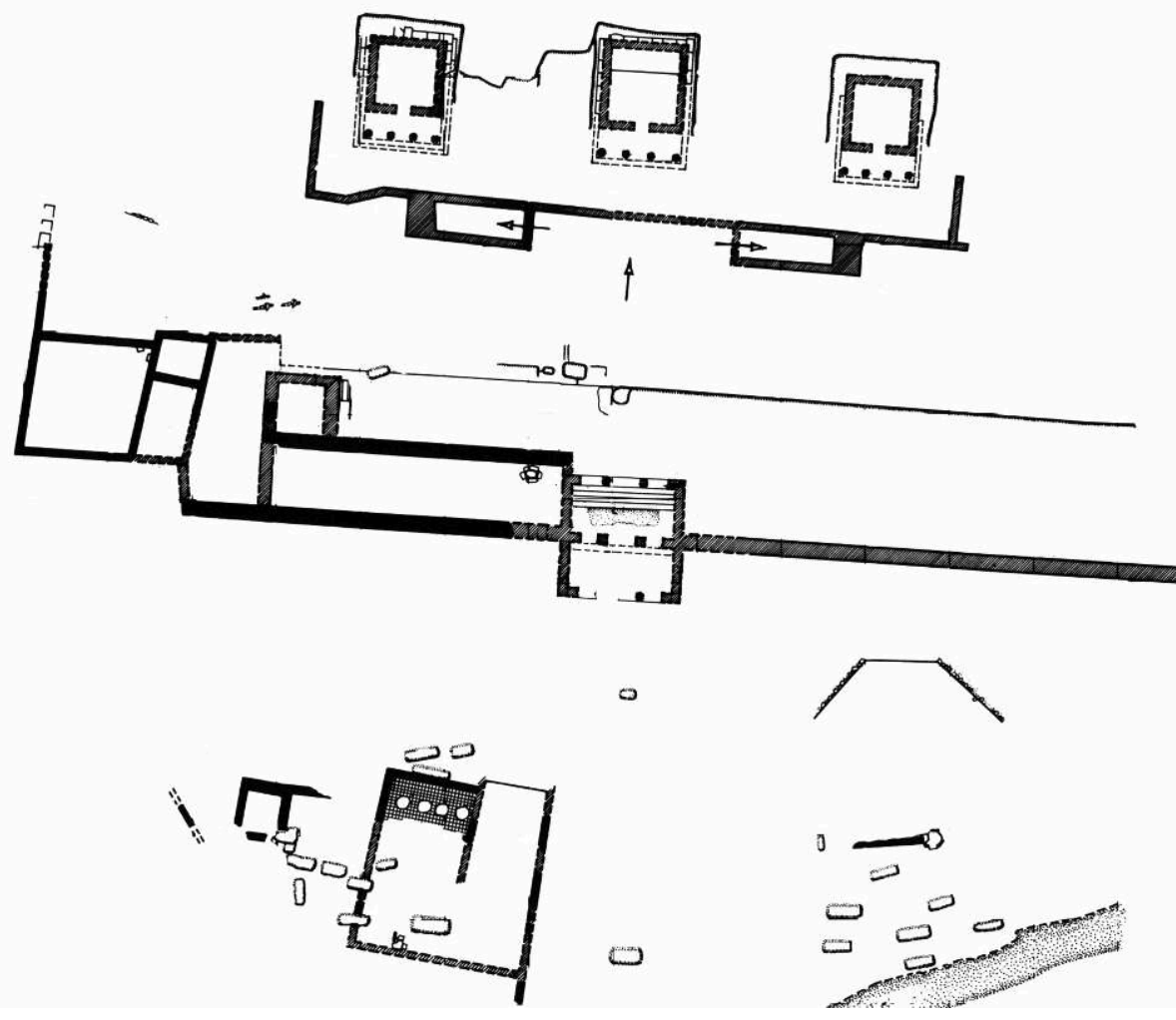

While Pausanias does not even attempt to characterize the ritual in any form, Plutarch and Lucian who also refer to the same ritual, describe it as a contest. ${ }^{15}$ At least two Roman inscriptions found in the sanctuary attest to the existence of the so-called "victor at the altar" ( $\beta \omega \mu o v[\varepsilon]$ ixns) and, thus, confirm the characterization offered by the two ancient authors. ${ }^{16}$ The archaeological excavations at the sanctuary of Artemis give us significant information about the changes in its religious topography, which should be connected with the transformation of the ritual in form and content: For centuries, the sanctuary appears to have consisted exclusively of a small temple and an altar. Two marble prohedria thrones connected with some sort of a theatral area dating to the late Hellenistic period demonstrate, however, that the old ritual was

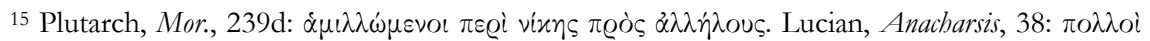

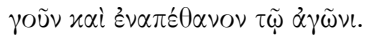

16 A.M. WOODWARD, "Inscriptions", in R.M. DAWKINS (ed.), The sanctuary of Artemis Ortbia at Sparta, JHS Suppl. 5, London, 1929, p. 356-358 nos. 143-144 (ca 200 AD). 
becoming more and more of a spectacle, in which obviously not only those directly participating were involved. ${ }^{17}$ The semantic swift in both the internal conception and the external visualisation and presentation of the ritual becomes evident in Roman Imperial times, and especially after the erection of a stone theatre for the numerous visitors around the altar at the beginning of the third century AD. ${ }^{18}$ Despite the well-known fact that theatres were important stages for ritual activity of almost any kind - especially from the Hellenistic period onwards,- 19 there is a clear difference between the use of an already existing structure and the erection of a new edifice for a very specific ritual, as in the case of the theatre around the altar of Artemis Orthia.

The most remarkable changes in ritual activity are normally connected with severe historical breaks. Despite the significant social, political, and nonetheless cultural developments of the Hellenistic era, it is mainly during the first century $\mathrm{BC}$ and the early Imperial period, with the foundation of Roman colonies in West Greece, Macedonia, and the Peloponnese, that Greek religion is permanently confronted with a similar, yet nevertheless conceptually different religious system. ${ }^{20}$ Recently, V. Pirenne-Delforge has convincingly shown that the intriguing sacrifice for Artemis Laphria in Patrai is a Roman invention within the context of a preexisting Greek cult transferred from Kalydon to Patrai under Augustus after the foundation of the Roman colony. ${ }^{21}$ Unlike the detailed description of the ritual itself, Pausanias' information concerning the sanctuary of Artemis Laphria on the acropolis of Patrai is extremely superficial, and even ambiguous. The perieget informs us about the existence of a sanctuary on the acropolis adding that the name (the epiclesis) is foreign and that the cult statue was brought to Patrai from Kalydon. ${ }^{22}$ We cannot be sure, whether we are dealing with a new foundation or a rededication of an older sacred area. And yet, when Pausanias comes to the description of the sacrificial ritual, he refers in detail to the altar and the ephemeral wooden structures

${ }^{17}$ I. NiELSEN, Cultic Theatres and Ritual Drama, Aarhus, 2002, p. 89.

18 R.M. Dawkins, “The History of the Sanctuary", in Dawkins (ed.), o.c. (n. 16), p. 37-47.

19 A. Chaniotis, "Theatre Rituals", in P. Wilson (ed.), The Greek Theatre and Festivals. Documentary Studies, Oxford, 2007, p. 48-66.

${ }^{20}$ Paus., II, 3, 7, referring to the cult of Medea's children in Corinth, describes an interesting case of total discontinuity of ritual activity.

21 V. Pirenne-Delforge, "Ritual Dynamics in Pausanias: The Laphria", in E. StavriANOpOulou (ed.), Ritual and Communication in the Graeco-Roman World, Liège, 2006 (Kernos, Suppl. 16), p. 111-129. This hypothesis was first, very briefly expressed by U. V. WiLAmowiTZMoellendorfF, Der Glaube der Helllenen, Berlin, 1931, p. 387 in a few words: "Da ist es gewagt, die Praxis der Antoninenzeit in die Urzeit zu verlegen. Vor diesem Anachronismus sich zu hüten, möge die Laphria von Patrai überhaupt warnen.”

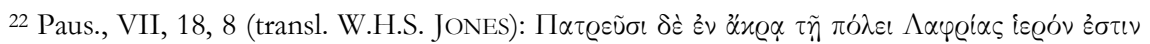

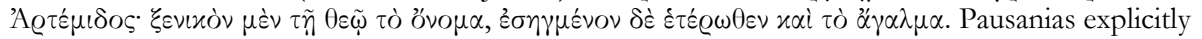

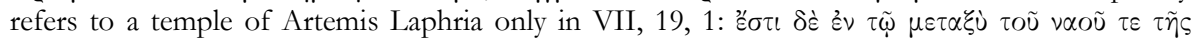
$\Lambda \alpha \varphi \varrho i \alpha$ к каі тои̃ $\beta \omega \mu о \tilde{\text {. }}$ 
surrounding it during the sacrifice: "Round the altar in a circle they set up logs of wood still green, each of them sixteen cubits long. On the altar within the circle is placed the driest of their wood. Just before the time of the festival they construct a smooth ascent to the altar, piling earth upon the altar steps." 23 The sacrifice took place at the altar, which must have been on the acropolis. If we take into consideration the number and diversity of the sacrificial animals thrown alive into the flames (edible birds, wild boars, deer, gazelles, wolf-cubs, bear-cubs), we must conclude that the altar was indeed huge. Even if the temple of Artemis Laphria was an older edifice rededicated to the new goddess under Augustus, the altar was presumably created anew for the needs of the strange sacrificial ritual and certainly presented a big permanent change in the architectural and topographical layout of the acropolis. Every year, at the celebration of the Laphria the sacred space around the altar was temporarily modified through the logs of wood. They obviously had a practical purpose, keeping the wild sacrificial animals inside the ephemeral precinct, but, at the same time, they almost created a sacrificial arena as it were combining the idea of Gúelv with a Roman venatio, which was normally not conceived as a form of sacrifice.

The changes in the religious topography of sanctuaries after the foundation of a Roman colony on the Peloponnese are even more striking in two of the most important sanctuaries of Corinth: the sanctuary of Poseidon at Isthmia and the sanctuary of Demeter and Kore on Acrocorinth. According to the scarce evidence, the sacrificial meal was the most important ritual action in the sanctuary of Demeter and Kore, for numerous banqueting rooms impressively dominated the architectural design of the cult area. ${ }^{24}$ The archaeological finds seem to indicate that the communal meal following the sacrifice gained enormous importance in the course of the sixth century BC, displaying an almost institutional character; it remained the dominant ritual activity as regards the architectural layout of the sanctuary until the destruction of Corinth in 146 $\mathrm{BC}$ and the subsequent abandonment of the cult place, which was, however, spared by the destructive rage of the Romans. Soon after the foundation of the Roman colony Laus Iulia Corinthiensis in $44 \mathrm{BC}$, the sanctuary was put into use again. Both the religious topography of the sanctuary and the character of the cult obviously underwent severe changes. Communal cult feasting clearly no longer played any role, since only one of the banquet buildings survived in a modified form serving a much different cause. The most striking novelty was, however, the erection of three small temples with identical floorplans on the

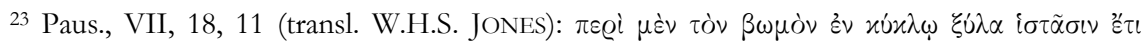

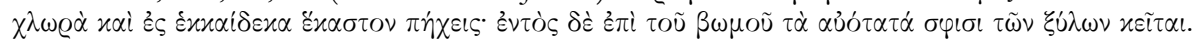

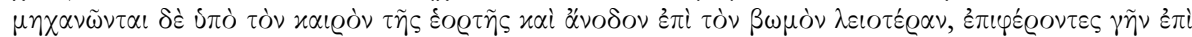

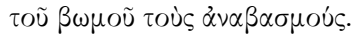

${ }^{24}$ N. BookIDIS, R.S STRoud, Corinth XVIII, 3: The Sanctuary of Demeter and Kore. Topography and Architecture, Princeton, 1997, passim. 
upper terrace of the sanctuary during the second half of the first century AD. ${ }^{25}$ Very probably, the three cult buildings may be identified as the temples of Demeter, Kore and the Fates seen by Pausanias in the second century AD (Fig. 1 above p. 55). ${ }^{26}$ It is intriguing that after a period of more than 700 years, during which the sanctuary had no need of a temple complex, the layout of the sanctuary became more canonical upon the arrival of the Roman colonists. The important differences between the Greek and Roman conceptions of the sacrificial meal most probably led to a fundamental shift of importance between the different ritual activities in the sanctuary, and in consequence to the radical remodelling of the architectural layout of the precinct. ${ }^{27}$

The Panhellenic sanctuary of Poseidon at Isthmia experienced the same fate of an almost total negligence after the destruction of Corinth, with its altar being partially destroyed and roads bypassing the area just to the north of the temple, thus, profanating an important part of the inner temenos. Just as in Olympia or Nemea, the cult of the main divinity, Poseidon, was complemented by the cult of a hero, the heroised child Melikertes/Palaimon. ${ }^{28}$ Despite the fact that the earliest explicit reference to a cultic "honour to be seen from afar"

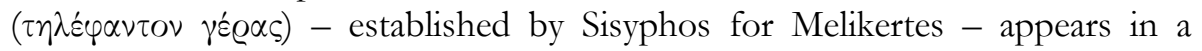
fragmentary Isthmian Epinician poem of Pindar from the early fifth century

${ }^{25}$ N. Bookidis, "The Sanctuaries of Corinth", in C.K. Williams II, N. Bookidis (eds.), Corinth XX: Corinth, The Centenary 1896-1996, Princeton, 2003, p. 257.

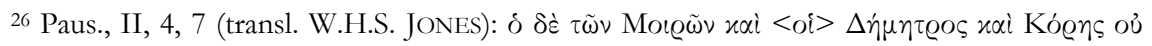

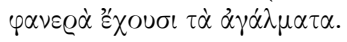

${ }^{27}$ J. MYLONOPOUlOS, "Greek Sanctuaries as Places of Communication through Rituals: An Archaeological Perspective", in Stavrianopoulou, o.c. (n. 21), p. 80-83; id., "Opferrituale in Griechenland und Rom. Eine vergleichende Perspektive", Polifemo 6 (2006), p. 191-208.

${ }^{28}$ In the most recent, extensive study of the cult of Palaimon, mainly based on the literary sources and the iconographical evidence (C. Ondine PACHE, Baby and Child Heroes in Ancient Greece, Chicago, 2004, p. 135-180), the author remains descriptive and presents the evidence without any significant new insights. She uncritically repeats traditional hypotheseis, such as that the athletes were the ones who took the oath in the adyton of the Palaimonion: Pausanias (II, 2, 1) does refer to the oath, but does not specify whether it is an athletes' oath or not; the connection between the oath in the adyton of the Palaimonion and the athletes is an assumption expressed by $\mathrm{O}$. Broneer. The author refers to the temple of Palaimon as a tholos and not as a monopteros, the archaeologically and architecturally correct term. The iconographical evidence delivered by the pinakes from Penteskouphia is referred to, but without any mention of the possibility that the fragmentary youthful figure depicted on two pinakes seated on a sea monster and a dolphin respectively could actually have represented Poseidon, although there is at least one pinax depicting indeed the youthful, beardless Poseidon fighting with his trident. The problem of the adolescent standing alive on the back of a dolphin on some Corinthian coins and its connection to a mythical tradition, which would in fact contradict the myth of the dead boy's body brought by a dolphin to the Corinthian seashore, is only discussed in a footnote and briefly explained with the duality of the dead hero child and its living divinised counterpart. The problem of continuity or discontinuity between the Greek and Roman implementation of the cult are only randomly addressed and the author does not clearly expresses her views on this important issue. 
$\mathrm{BC},{ }^{29}$ there is no secure evidence whatsoever for the existence of a cult precinct for the child hero within the sanctuary of Isthmia before the first century AD. ${ }^{30}$ Furthermore, the Pindaric poem most probably refers to a tomb or a precinct like the Pelopion or the Ophelteion, near the sea. All the information concerning the actual cult practices in honour of Melikertes/Palaimon is of Imperial date. The first Palaimonion, a simple sacrificial pit for the holokaust, dates according to the relevant pottery to the mid-first century AD. While most scholars either tried to discover the Greek origins of the Melikertes/Palaimon cult at Isthmia based solely on literary and epigraphic sources of Roman date ${ }^{31}$ or even dated the emergence of the cult in the Imperial period based on the same evidence, ${ }^{32}$ M. Piérart convincingly argued that the cult of Melikertes/ Palaimon was certainly Greek but, in the form in which we can grasp it on the basis of the archaeological remains and written sources, it was actually reinvented by the Roman colonists of Corinth. ${ }^{33}$ The reinvented cult needed

29 Pindar, fr 6 (ed. B. SNell, H. MAeHLeR).

30 In my own book on the sanctuaries of Poseidon on the Peloponnese, I expressed the hypothesis of Melikertes/Palaimon being venerated together with Dionysos in the so-called NE cult cave and later in the so-called theatre cave, cf. MYLONOPOULOS, o.c. (n. 7), p. 184-186. $196 \mathrm{f}$.

31 E. WiLl, Korinthiaka. Recherches sur l'histoire et la civilisation de Corinthe des origines aux guerres médiques, Paris, 1955, p. 168-180 even considered the cult of Melikertes/Palaimon to be preGreek.

32 J.G. HAWTHORNE, “The myth of Palaimon”, TAPhA 89 (1958), p. 92-98.

33 M. PIÉRART, "Panthéon et hellénisation dans la colonie romaine de Corinthe: la «redécouverte» du culte de Palaimon à l'Isthme”, Kernos 11 (1998), p. 85-109. While I wholly accept Piérart's idea about the 'rediscovery' of the cult of Melikertes/Palaimon after the foundation of the Roman colony at Corinth, I fail to recognise any cultic connection between Palaimon and Portunus at Isthmia, which supposedly led to the 'rediscovery' of the Greek cult by the Roman colonists (in his Fasti, VI, 538-552 and Metamorphoses, IV, 416-542, Ovid seems to be the first to identify Palaimon with Portunus and Ino with Mater Matuta). Piérart's further hypothesis that not only the foundation of the Antonine monopteros but also the reestablishment of the cult of Palaimon should be connected with the incidental discovery of the water reservoir of the early stadion in Imperial times contradicts the evidence from the sacrificial pits and should be dismissed because of the existence of an earlier Hadrianic monopteros without any spatial interconnection with water facilities. E. GEBHARD, "Rites for Melikertes-Palaimon in the Early Roman Corinthia", in D.N. Schowalter, S.J. FrIESEN (eds.), Urban Religion in Roman Corinth. Interdisciplinary Approaches, Cambridge Mass., 2005, p. 165-203 argues in favour of a continuation of the cult practices without any break between the Greek and Roman cultural phases of Corinth. She reconstructs holocausts for the period before $146 \mathrm{BC}$ using however the well-known literary sources of the Imperial period (p. 174-181). Gebhard emphasises the importance of a fragment by Euphorion (third century BC), which describes men placing the dead body of a youth (Melikertes?) on pine boughs while lamenting (This variation of the myth cannot be seen as an attempt to immortalize the child by placing it in the fire, of. on babies immortalized through fire B. Currie, Pindar and the Cult of Heroes, Oxford, 2005, p. 383-385). Even if the fragmentary poem of Euphorion does describe a ritual mimesis of Melikertes' funeral, it cannot be used as an argument for the unchanged continuity of cult practices in honour of Melikertes/Palaimon. Gebhard accepts Piérart's hypothesis that the abandoned water reservoir played a constitutional role in the formation of Palaimon's cult at Roman Isthmia (p. 197-200), and suggests that it was 
the adequate facilities, so that between the mid-first and the late second century $\mathrm{AD}$ three sacrificial pits and two monopteroi were established to the east and later to the south of Poseidon's temple, in order to accommodate the cult of the child hero. It is not at all certain, that the holocaust for Palaimon - "the only osteologically demonstrated case" 34 - had its counterpart in the Greek cult of the hero. It is more probable that the sacrifice to Melikertes/Palaimon in the Classical to Hellenistic periods was quite different. Fact is, that the new facilities for the Roman cult of Palaimon dramatically changed the image of the sanctuary, and especially the area in the immediate vicinity of the temple for the main divinity, an area, which apparently remained untouched by any building activity worth telling for centuries (Fig. 2).

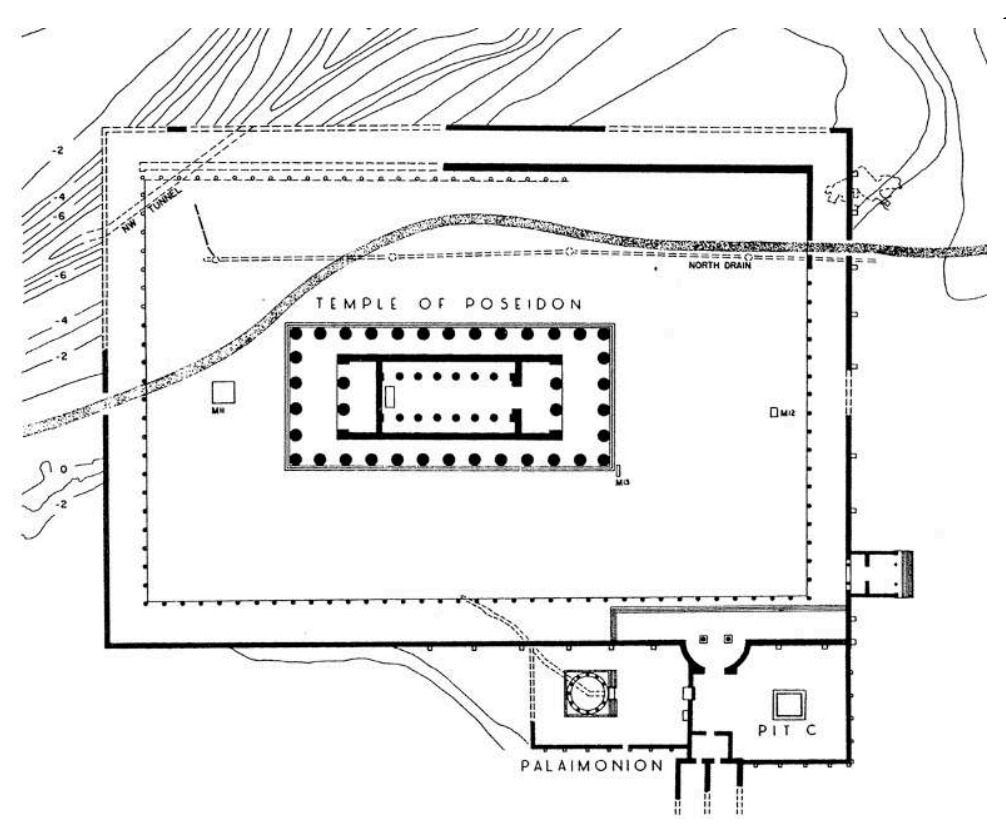

Fig. 2

\section{Transmitted rituals - "copied" places}

During the fifth century $\mathrm{BC}$ a certain number of new cults entered the Athenian pantheon. At first glance, for none of them is the literary, archaeological and epigraphic evidence as rich as that concerning the case of the introduction of the Asklepios cult in the last quarter of the fifth century. For no

used as the adyton described by Pausanias, already during the Flavian phase of Palaimon's precinct.

${ }^{34}$ G. Eкroth, The Sacrificial Rituals of Greek Hero-cults in the Archaic to the early Hellenistic Periods, Liège, 2002 (Kernos, Suppl. 12), p. 124. 
other cult foundation do we possess such an invaluable document as the fragmentary so-called stele of Telemachos, pieces of which are kept in Athens, London, Padua, and Verona. ${ }^{35}$ The text gives most important and detailed information about the procedures regarding the ritual introduction of the new god into Athens via Piraeus by the Athenian Telemachos in 420/19 BC and the foundation of the sanctuary at the south slope of the Acropolis after the great plague. ${ }^{36}$

The remains of the sanctuary were excavated in 1876 and 1877, but the architecture has never received the publication it certainly deserves. Moreover, the preconceived opinion that we are dealing with an absolutely private foundation created the idea of a sanctuary with a modest architectural setting. The reference to a wooden gate in the aforementioned inscription supported the idea of a precinct with temporary wooden architecture, if any, replaced after the middle of the fourth century by stone structures. J. Riethmüller most convincingly reconstructed the architectural and topographical development of the Asklepieion in his doctoral thesis. ${ }^{37}$ The sanctuary seems to have been limited to the so-called east terrace, as the existence of an easily recognisable peribolos wall demonstrates. Attempts to attribute the banquet house also known as 'West' or 'Ionic' stoa to the Asklepios sanctuary are unfounded. We know from Pausanias that a number of sanctuaries lay to the west of the Asklepieion, ${ }^{38}$ and visitors to these could have used the banquet house. The sanctuary seems to have at least three construction phases. In the first phase, attributed by Riethmüller to the Telemachian foundation, poros stone was used almost exclusively. Part of the peribolos wall, the cella of the temple, the west part of the altar, and the lower part of the so-called bothros belonged to this phase. It remains uncertain whether the spring in the Acropolis rock, normally identified with the Hallirhotis spring seen by Pausanias (I, 21, 4), predates the foundation of the sanctuary or not. In the late fourth or early third century the

35 L. BESCHI, "Il monumento di Telemachos, fondatore dell'Asklepieion Ateniese", AS Atene 45/46 (1967/68), p. 381-436. K. Clinton, "The Epidauria and the Arrival of Aclepius in Athens", in R. HÄGG (ed.), Ancient Greek Cult Practice from the Epigraphical Evidence, Proceedings of the Second International Seminar on Ancient Greek Cult, organized by the Swedish Institute at Athens, 22-24 November 1991, Stockholm, 1994, p. 17-34.

36 According to R. Mitchell-BOyASK, Plague and the Athenian Imagination. Drama, History, and the Cult of Asclepius, Cambridge, 2008, p. 105-121 the sanctuary of Asklepios was founded at this specific part of the Athenian acropolis, because of its vicinity to the temple and theatre of Dionysos. There is perhaps an interesting parallel between the arrival of Epimenides in Athens upon Solon's invitation in order to drive away the plague that ravaged the city after the Kylonean taint and the arrival of Asklepios upon Telemachos' 'invitation' after the plague that decimated the population of Athens in 430-426 BC.

${ }^{37}$ Riethmüller, o.c. (n. 9), p. 241-278. See also S.B. Aleshire, The Athenian Asklepieion. The People, their Dedications, and the Inventories, Amsterdam, 1989, p. 7-37 for a reconstruction of the sanctuary's historical development, based primarily on the written sources.

38 Paus., I, 22, 1-3. 
large stoa was built and the so-called bothros received a roof supported by four columns (Fig. 3). It remains unclear, when the temple and the altar were enlarged, the East stoa remodelled and the South stoa added. At any case, the south stoa is a Roman construction. An inscription dating to 52/51 BC refers to the petition of Diokles, a priest of Asklepios and Hygieia, to finance restorations to the temple and the propylon. ${ }^{39}$ It is tempting to connect this restoration to an overall remodelling of the sanctuary, but there is no evidence to support or reject such a hypothesis.

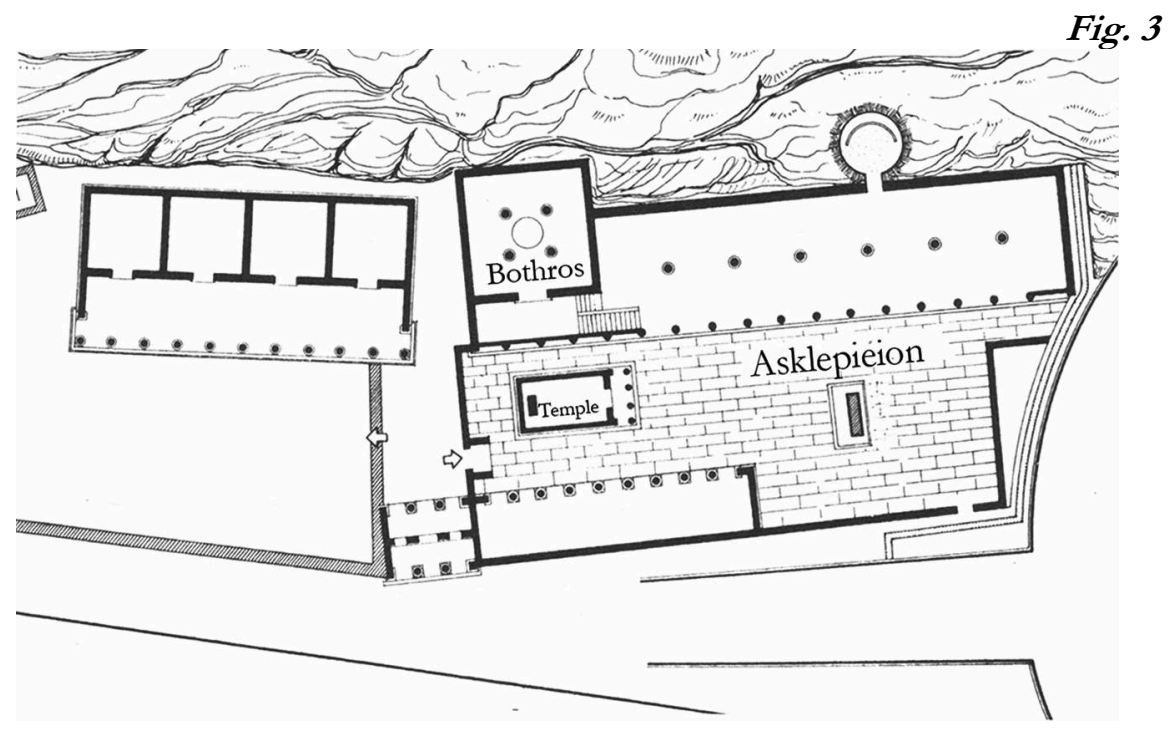

The architectural layout of the Athenian Asklepieion with its temple, altar, spring, and bothros covered by a tetrastylon was certainly not an incidental development, but seems to be a very conscious functional and organisational measure modelled after the Epidaurian sanctuary. It was again Riethmüller who demonstrated that the tholos for the cult of Asklepios as a hero and the temple for his cult as a god in Epidauros find their Athenian counterparts in the bothros and small temple respectively. ${ }^{40}$ The interconnections between the

${ }^{39} I_{G} \mathrm{II}^{2} 1046$.

40 J. RiEThmüller, "Bothros and Tetrastyle: The Heroon of Asclepius in Athens", in R. HÄGG (ed.), Ancient Greek Hero Cult, Proceedings of the Fifth International Seminar on Ancient Greek Cult, organized by the Department of Classical Archaeology and Ancient History, Göteborg University, 21-23 April 1995, Stockholm, 1999, p. 123-143. RiETHMÜLLER, o.c. (n. 9), p. 360-392 demonstrates anew that in respect to architectural layout and organisation of sacred space, there was indeed a very special interrelation between the Athenian Asklepieion and the sanctuary in Epidauros, but the connection between other Asklepieia (e.g. in Balagrai, Lebena, or Pergamon) and Epidauros remain more vague. A. VERBANCK-PIÉRARD, "Les héros guérisseurs: des dieux comme les autres! À propos des cultes médicaux dans l'Attique classique", in V. PirenNe-DeLforge, E. SuÁrez DE LA TORRE (eds.), Héros et héroïnes dans les mythes et les cultes grecs, Liège, 2000 (Kernos, 
Athenian and the Epidaurian Asklepieion apparently go beyond these central cult edifices. A fragment of the aforementioned Telemachos stele documents for the year 413/12 BC (under the archonship of Kleokritos) the creation of a (sacred?) grove and further decoration in the temenos. ${ }^{41}$ As F. Graf has pointed out, sacred groves seem to be a constitutive element of Greek Aklepieia, ${ }^{42}$ and in Epidauros there was certainly one, ${ }^{43}$ perhaps of olive trees, as suggested by an inscription referring to a procession, during which the participants were holding olive branches. ${ }^{44} \mathrm{~A}$ sacred grove of olive trees and olive wreaths are documented for the Asklepieia in Epidauros Limera ${ }^{45}$ and Pergamon ${ }^{46}$ respectively. It becomes apparent that several important elements of the Epidaurian cult topography were introduced into the Athenian branch, and yet the procedure of the transmission did not end up with a slavish copy of the sanctuary in Epidauros, but, rather, with a dynamic adjustment of the architectural elements in their new topographical context.

The Athenian Asklepieion is certainly not a unique case of a newly founded cult that required not only the transmission of the respective rituals, but also a

Suppl. 10), p. 329-332 dismisses the reconstruction of the double nature of Asklepios' cult in his Athenian sanctuary with arguments that I do not find convincing: The fact that the term 'bothros' is indeed in the archaeological bibliography ambiguously used, does not in any form weakens the identification of the 'opening' as a place for sacrificial rituals, for a terminological problem cannot be used as an argument against an interpretation. Verbanck-Piérard favours the interpretation of the 'opening' as a water reservoir (already suggested by S.B. Aleshire). It is indeed possible, but it is definitely not the only way to interpret the 'opening'. As a third argument against Riethmüller's hypothesis the author states: "rien n'autorise l'interprétation de la fosse comme un bothros sacrificiel." While this is again true, there is indeed no secure evidence for the identification of the "fosse" as a place for the sacrifice to the hero Asklepios, we should also consider the fact that a festival in honour of Asklepios is called the Heroia, a detail, which the author prefers to silently pass over. While I would agree with Verbanck-Piérard about the practical problems connected with a possible blood offering at the bothros, as suggested by Riethmüller, I would prefer to rethink only the reconstruction of the sacrifice's form, and not the general concept of the double nature of Asklepios in Athens itself. Most recently, MiTCHELLBOYASK, o.c. (n. 36), p. 115-117 stressed the architectural and structural uniqueness of the Athenian Asklepieion. The author based, however, his assumption solely on F. Graf's article on Greek Asklepieia of 1992 ignoring Riethmüller's articles and above all his monumental two volume doctoral thesis. Mitchell-Boyask's book, which is actually full of intriguing ideas, presents, nevertheless, an example for the limitations imposed on a study almost exclusively based on a single category of evidence (in this case Athenian tragedies).

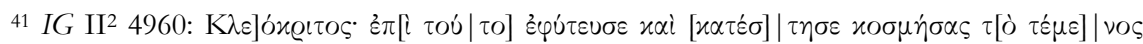
$\ddot{\alpha} \pi \alpha \nu \tau \dot{\varepsilon} \lambda \varepsilon[\iota \tau \tilde{\omega} \iota \varepsilon \alpha u \mid \tau] \hat{o}$.

${ }^{42}$ F. GRAF, "Heiligtum und Ritual. Das Beispiel der griechisch-römischen Asklepieia", in A. SCHACHTER (ed.), Le sanctuaire grec, Geneva, 1992 (Entretiens sur l'Antiquité classique, 37), p. 181186. .

43 Paus., II, 27, 1

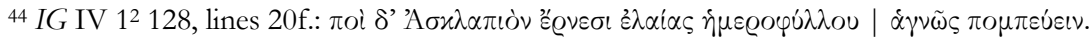

${ }^{45}$ Paus., III, 23, 7.

46 M. WÖrrle, "Die Lex sacra aus der Hallenstraße (Inv. 1965, 20)", in Chr. HABicht, Die Inschriften des Askelepieions, Berlin, 1969 (AvP, 8.3), p. 167-190 (A, lines 2f: $x \alpha[i] \lambda \alpha \beta \dot{\omega} v \alpha \ddot{\alpha} \lambda \lambda o v$

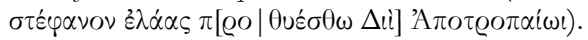


recreation with necessary adjustments of the original architectural and topographical setting. One can here include, e.g., the construction of artificial caves for the celebration of the Mithraic mysteries or for Dionysiac cults.

Perhaps the most illustrative example for the transmission of elements of the original sacred place into a new environment is the imaginative recreation of Nilotic landscapes in sanctuaries of the Egyptian deities outside Egypt. In the cults of Isis and Sarapis water had an important role. Many of the Egyptian ceremonies were tightly connected with the river Nile. Participants at numerous festivals in Egypt drank the holy water of this river, which was in many cases identified with Osiris. ${ }^{47}$ Such rituals concerning holy water were transmitted together with the cult of the Egyptian deities and required an adequate architectural setting. Most of the sanctuaries for the Egyptian deities have water facilities in some form. ${ }^{48}$ Best documented are such constructions in the sanctuary at Gortyn on Crete, in the Sarapeia on Delos, and in the sanctuary of Isis at Pompei. ${ }^{49}$ The literary sources attest to the firm belief of the cult participants that the water in such sacred places was indeed water from the river Nile.

In Pergamon, German archaeologists are currently studying a huge sanctuary $($ ca $270 \times 100 \mathrm{~m})$ dedicated in all likelihood to the Egyptian deities. ${ }^{50}$ The

${ }^{47}$ B. GESSLER-LÖHR, Die heiligen Seen ägyptischer Tempel: Ein Beitrag zur Deutung sakraler Baukunst im Alten Ägypten, Hildesheim, 1983; K. LEMBKE, "The Relevance of Water in Religious Worship of Ancient Egypt and the Middle East", in H.-D. BIENERT, J. HÄSER (eds.), Men of Dikes and Canals. The Archaeology of Water in the Middle East, Rahden, 2004, p. 301-305. See for example the importance of the Nile in the Osiris procession during the khoiak festival in Abydos, A. KuChAREK, "Die Prozession des Osiris in Abydos. Zur Signifikanz archäologischer Quellen für die Rekonstruktion eines zentralen Festrituals", in MYLONOPOULOS - ROEDER, o.c. (n. 13), p. 5364; R.J. Leprohon, "Ritual Drama in Ancient Egypt", in E. CsApo, M.C. Miller (eds.), The Origins of Theater in Ancient Greece and Beyond: From Ritual to Drama, Cambridge, 2007, p. 261-269.

48 Cf. Apuleius, Metamorphoses XI, 20: et per dispositas aras circumiens sacerdos, rem divinam procurans supplicamentis sollemnibus, de penetrali fontem petitum spondeo libat.

49 Ph. BRUNEAU, Recherches sur les cultes de Délos à l'époque hellénistique et à l'époque imperiale, Paris, 1970, p. 457-480; R. SALDITT-TRAPPMANN, Tempel der ägyptischen Götter in Griechenland und an der Westkïste Kleinasiens, Leiden, 1970 (EPRO, 15); H. KOESTER, "The Cult of the Egyptian Deities in Asia Minor", in id. (ed.), Pergamon - Citadel of the Gods. Archaeological Record, Literary Description, and Religious Development, Harrisburg, 1998, p. 111-135; M. Bommas, Heiligtum und Mysterium. Griechenland und seine ägyptischen Gottheiten, Mainz, 2005; B.B.M. ÜNLÜOĞLU, "The Cult of Isis in Asia Minor", in HofFMANN, o.c. (n. 8), p. 95-108.

${ }^{50}$ K. LemBKE, "Kolossalität und Monumentalität: Zur Größe und Ausdehnung der Roten Halle", in HofFmanN, o.c. (n. 8), p. 47-57. The author sees Hadrian as the initiator of this project, which - according to LEMBKE - was originally conceived as a temple for the cult of the emperor with Antinoos as a synnaos after his death. The death of Hadrian's favourite in the Nile and his primary deification first in Egypt would explain the Egyptianizing sculpture and the presence of water facilities. It seems to me improbable that such a massive building project connected with the cult of the emperor and his favourite would have left no trace whatsoever in the written sources. In her published $\mathrm{PhD}$ thesis, the author was apparently more sceptical towards the alleged role of Hadrian in promoting the Egyptian cults, of. K. LEMBKE, Das Iseum Campense in Rom: Studie über den Isiskult unter Domitian, Heidelberg, 1994, p. 136: "m.E. ist überhaupt die 
sanctuary was most probably constructed during the reign of Hadrian. ${ }^{51}$ The temple building is a brick construction that consists of three shrines and a big courtyard. The middle shrine, the so-called Red Hall, dominates the central part of the modern city of Bergama. The space in front of the East wall of the temple's middle part is occupied by a big platform, the podium for the cult statue is situated on it. In front of the platform, there is an oblong trench and a water basin with three marble troughs. The underground space beneath the platform was used as a cistern. In front of the side-shrines, there were also water facilities in the form of twin basins (Fig. 4). It is most probable that the water in the temple of Pergamon was understood as the Nile and was used for rituals concerning the cult statue (for example bathing), while the cistern could be a substitute for the headwaters of the Nile. ${ }^{52}$ The Egyptianizing sculpture certainly emphasized the impression of a Nilotic environment. ${ }^{53}$

Fig. 4

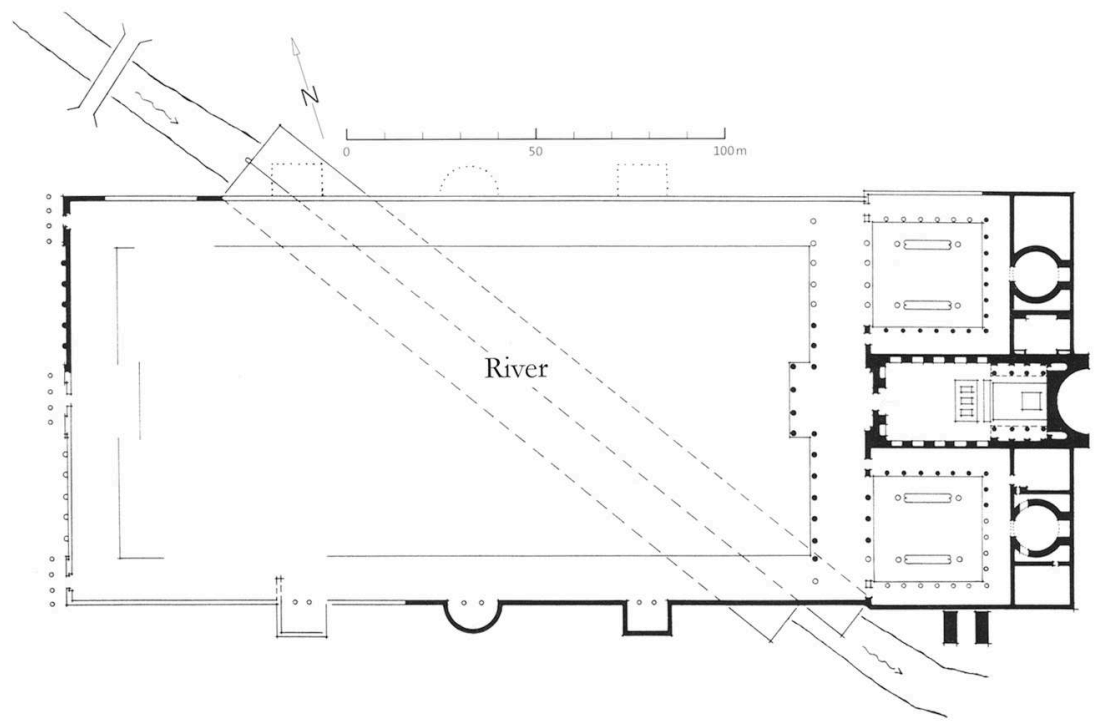

A further example of the virtual presence of the Nile in a sanctuary outside Egypt was excavated at the city of Dion in Macedonia. Here, the cult of Isis seems to have replaced an older cult of Artemis already in the second century

Bedeutung Hadrians hinsichtlich der ägyptischen Religion im imperium Romanum überschätzt worden."

${ }^{51}$ Despite the fact that there is absolutely no historical evidence, the idea of Hadrian being the initiator and financer of this project is very widespread, $c$. A.-K. RIEGER, "Pergamon und Rom. Überlegungen zur städtebaulichen Bedeutung und zur Bauherrschaft der Roten Halle in Pergamon", in Hoffmann, o.c. (n. 8), p. 81-94.

52 W. RADT, Pergamon. Geschichte und Bauten einer antiken Metropole, Darmstadt, 1999, p. 200-209.

53 U. MAnia, "Neue Ausgrabungen - neue Aspekte in der Erforschung der Roten Halle", in HofFmanN, o.c. (n. 8), p. 30-32, fig. 6, 8. 
$\mathrm{BC}$, but the architectural remains of the Isis sanctuary date to the second and third centuries AD. The topography of the sanctuary presents a combination of different cults (Isis Lochia, Isis Tyche, Aphrodite Hypolympia) with apparently various water facilities. The central podium temple is dedicated to Isis Lochia with an altar in front of the temple, and just behind it to the east, the beginning of a long trench flanked by parapet walls with columns on their top. The trench is connected to the water reservoir underneath the temple of Aphrodite Hypolympia to the north of the temple of Isis Lochia and symbolizes the Nile. In Dion the concept of a 'man made' Nile is even better realized than in Pergamon in form of this trench. To the south of the central building stands the temple in honour of Isis Tyche with her cult statue found in situ in the apsis during the excavations. An oval shaped water basin was found in front of the statue. ${ }^{54}$ In the Isis sanctuary of Dion water was literally omnipresent.

\section{Ethnically and / or religiously defined groups in an alien environment}

The cult of the Egyptian deities outside Egypt represents the case of a cult being transferred into a new cultural context bringing its own rituals and its own architectural design into the new setting, but remaining open for participants interested in the new cult. A 'missionary' character is obvious: the transfer of the cult of the Egyptian deities was not strictly connected to a specific, closed group wishing to perform the rituals known from its homeland in separation from the indigenous population: such cults needed new followers in order to survive.

The numerous Diaspora synagogues represent an entirely different paradigm. A Diaspora synagogue fulfils the wish of a firmly defined group of people to perform their own rituals in adequate architectural settings in a geographically, culturally, and religiously alien context. The oldest and perhaps one of the most problematic Diaspora synagogues was excavated in 1912 on the small island of Delos, one of the most important ports of the Hellenistic world. ${ }^{55}$ The building stands today at $15.5 \mathrm{~m}$ long and $28.15 \mathrm{~m}$ wide, but it must

54 D. Pantermalis, "Ein neues Heiligtum in Dion", $A$ A (1982), p. 727-735; id., Discovering Dion, Athens, 2000, p. 89-117 (the analysis is kept to a minimum, but excellent photos of the architecture and the finds from the sanctuary are provided); M. BOMMAS, "Neue Heimat in der Fremde. Isis in Makedonien", AntW 31 (2000), p. 622 f.; Bommas, o.c. (n. 49), p. 100.

55 Bruneau, o.c. (n. 49), p. 480-493; A.Th. KraABEL, "The Diaspora Synagogue: Archaeological and Epigraphic Evidence since Sukenik", in D. Urman, P.V.M. FLESHER (eds.), Ancient Synagogues. Historical Analysis and Archaeological Discovery, vol. I, Leiden, 1995, p. 109-112. Because of the dedications set up by individuals bearing Greek names for Theos Hypsistos, D. NoY et al., Inscriptiones Judaicae Orientis. I Eastern Europe, Tübingen, 2004, p. 218 f. identify the building as an edifice used by a pagan cultic society under Jewish influence or by an association of Judaizers. 
have been larger in antiquity, since possible annexes remain unexcavated or have been destroyed by the intruding sea.

\section{Fig. 5}

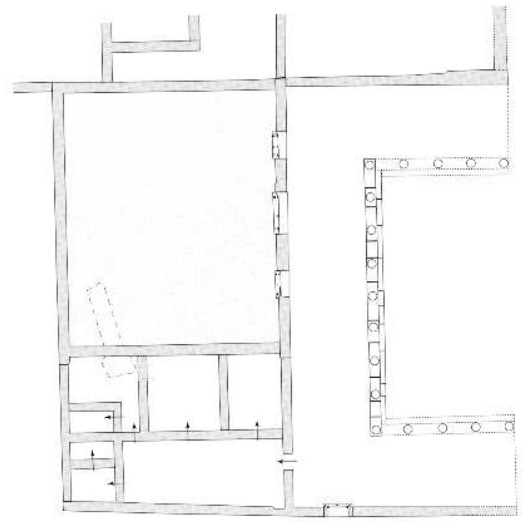

The synagogue was originally founded in the late second century BC. In a model study of the edifice, M. Trümper was able to demonstrate that the building was conceived and used as a synagogue from the very beginning and had six architectural phases of use (Fig. 5). ${ }^{56} \mathrm{It}$ is extremely difficult to develop a typology of the Diaspora synagogues, mostly because it is the specific functionality and not the strictly defined architectural design that characterizes these buildings. ${ }^{57}$ There are, however, some important aspects shared by most Diaspora synagogues. Archaeological discoveries from Ostia, Delos, Priene, Dura Europos, Gerasa, and Sardeis strongly suggest that water facilities (cisterns or fountains) and gathering halls were common features of Diaspora synagogues. In some cases the entrance area was occupied by colonnaded structures, precisely as in Delos. A further interpretive problem concerning the Delian synagogue is its actual attribution to a particular Israelitic religious group. For a long time the building was considered as the earliest example of a Jewish Diaspora synagogue. In 1980, however, two Samaritan synagogue inscriptions were found just $90 \mathrm{~m}$ north of the building, suggesting that the structure could have been a Samaritan, rather than a Jewish synagogue. ${ }^{58}$ In any case the Delian building is a good example of how the implantation of Near Eastern religious beliefs shaped sacred space in a new context because of the specific needs dictated by religious practices (especially physical purity, study, gathering, and

The authors suggest, however, an alternative interpretation of the building as the house of "a Jewish association that borrowed from or assimilated to pagan practice".

56 M. TRÜMPER, "The Oldest Original Synagogue Building in the Diaspora. The Delos Synagogue Reconsidered”, Hesperia 73 (2004), p. 513-598.

${ }^{57}$ E. Gruen, Diaspora: Jews Amidst Greeks and Romans, Cambridge Mass., 2002, p. 113-118. See on the architecture of synagogues in general: J. GuTMANN (ed.), The Synagogue: Studies in Origins, Archaeology and Architecture, New York, 1975; Urman - Flesher, o.c. (n. 55), passim. On the 'sanctity' of Diaspora synagogues see S. FINE, This Holy Place. On the Sanctity of the Synagogue During the Greco-Roman Period, Notre Dame, 1997, p. 127-157.

58 Ph. BRuneAu, "Les Israélites de Délos et la juiverie délienne", BCH 106 (1982), p. 467485; SEG 32, 809-810. For example B. HudSON MCLEAN, "The Place of Cult in Voluntary Associations and Christian Churches on Delos", in J.S. KLoppenburG, S.G. Wilson, Voluntary Associations in the Graeco-Roman World, London, 1996, p. 191-195 argues in favour of the interpretation of the building as a Samaritan synagogue. 
perhaps prayer ${ }^{59}$ ), without a slavish imitation of architectural design. In the case of the Diaspora synagogues, the sacred space is defined by the practical needs of the cult, and not by the blind orientation towards the place of religious origin. ${ }^{60}$

Polytheistic systems are of course less exclusive, and yet the profound need to transfer cults, rituals, and elements or concepts of the religious architecture from one's homecountry is also apparent among Greek merchants, colonists, and mercenaries. Naukratis, the "Greek" city in the Nile delta, is perhaps the most perspicuous case for the transfer of cults in the course of trade contacts, which led to the permanent presence of Greeks on Egyptian soil. According to Herodotos nine Greek cities (Chios, Teos, Phokaia, Klazomenai, Rhodos, Knidos, Halikarnassos, Phaselis, and Mytilene) founded a common sanctuary under the name Hellenion, while "the Aeginetans made a precinct of their own, sacred to Zeus, and so did the Samians for Hera, and the Milesians for Apollo." 61 Two more sanctuaries not mentioned by Herodotos were identified, which were dedicated to the Dioskouroi and to Aphrodite, the latter also known through later literary sources. ${ }^{62}$ There is nothing special about Greeks arriving in a foreign country and founding sanctuaries for their deities. ${ }^{63}$ Nevertheless, the discovery of so-called Hera cups produced on Samos and imported to Naukratis demonstrates the strong connections between the main sanctuary of Samos and the Samian sanctuary of Hera in Naukratis. ${ }^{64}$ These

${ }^{59}$ Note the critical remarks in D. URMAN, "The House of Assembly and the House of Study Are They One and the Same?", in URMAN - FleSHER, o.c. (n. 55), p. 232-255.

60 After a brief survey of six Diaspora synagogues, A. Th. KRAABEL, "Social Systems of Six Diaspora Synagogues", in J. GuTmanN (ed.), Ancient Synagogues. The State of Research, Ann Arbor, 1981 , p. 87 concludes "that the most important factors shaping a Diaspora synagogue building are local; location, size, decoration, architectural features and even symbolism depend in large part on the forces at work and the patterns available in a particular gentile city or town."

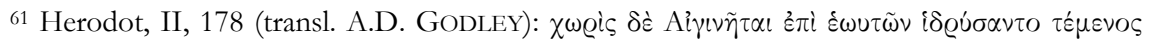

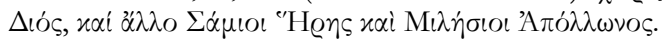

62 Athenaios, XV, 675f-676c: The dedication of an Aphrodite's statue to the precinct of the

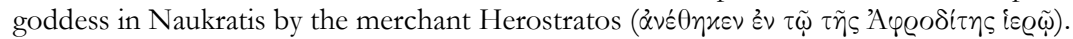

63 On the Naukratian sanctuaries see most recently A. MÖLLER, Naukratis. Trade in Archaic Greece, Oxford, 2000, p. 94-113. Important new insights about the cult of Apollon (identified as Apollon Didymeus Milesios) in Naukratis in A. HERDA, "Apollon Delphinios - Apollon Didymeus: Zwei Gesichter eines milesischen Gottes und ihr Bezug zur Kolonisation Milets in archaischer Zeit", in R. BOL et al. (eds.), Kult(ur)kontakte. Apollon in Myus, Milet/Didyma, Naukratis und auf Zypern. Akte der Table Ronde Mainz 11.-12. März 2004, Rahden, 2008 (forthcoming). I would like to thank A. Herda for allowing me to use his unpublished manuscript.

64 U. SCHLOTZHAUER, "Griechen in der Fremde: wer weihte in den Filialheilgtümern der Samier und Milesier in Naukratis?", in A. NASO (ed.), Stranieri e non cittadini nei santuari greci, Florence, 2006, p. 311-313, fig. 11-13. The Chian pottery was also produced in Chios and not in Naukratis, but in this case we are dealing with votive offerings, which could be used in cult, but were, nevertheless, not exclusively produced for cultic use, cf. D. WiLliams, "The Chian Pottery from Naukratis", in A. Villing, U. SchlotZHAUER (eds.), Naukratis: Greek Diversity in Egypt. Studies on East Greek Pottery and Exchange in the Eastern Mediterranean, London, 2006, p. 127-132. 
plain cups with Hera-dipinti were produced only on Samos and were used exclusively in the cult of Hera. ${ }^{65}$ Their discovery in Naukratis means that the Samian inhabitants of Naukratis not only introduced their general religious concepts, but, moreover, that ritual practices were apparently reproduced in great detail abroad, so that the vessels used in the cult were directly imported in order to avoid potential ritual failures. The excavated remains at the Hera temenos in Naukratis do not allow any conclusions about possible interrelations between the Samian and Naukratian sanctuaries of Hera as regards spatial organisation and architectural design.

Fig. 6
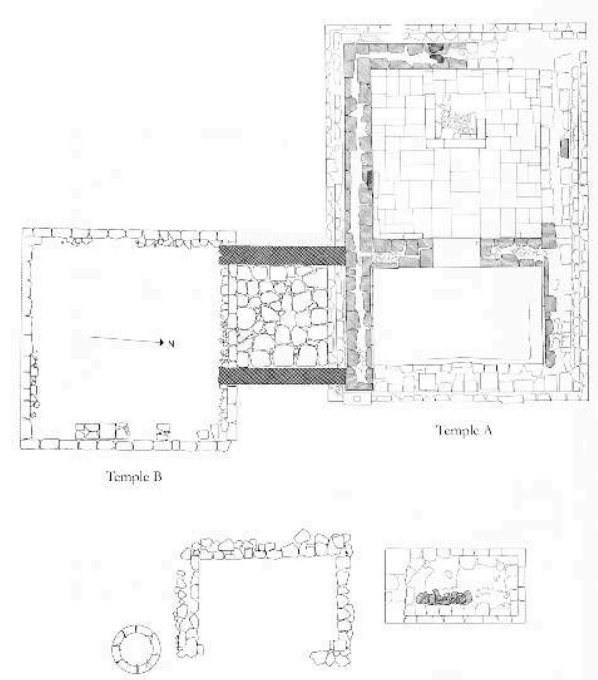

Ikaros (modern Failaka), a small island in the Arabian Gulf, is an excellent example for the transfer of Greek religious ideas and architectural forms through mercenaries, soldiers or immigrants. Danish archaeologists discovered in 1958 a Seleucid fortress, which according to the numismatic evidence was founded around the mid-third century BC. ${ }^{66}$ Within the fortress two temples dating to the third century were excavated. ${ }^{67}$ Almost nothing remains of the so-called temple $B$, apparently a Doric structure. Temple $A$ is a typical small Greek Ionic temple in antis without a peristasis (Fig. 6). While concept and design are Greek, the masonry techniques (for example the use of the pointed chisel) point to local traditions. ${ }^{68}$ In 1982 French archaeologists discovered directly by the sea to the southeast of the fortress a small temple of a quite unusual plan consisting of a small naos, a wider pronaos and an open courtyard (almost half of the building is now lost). A painted dedication on an altar identifies the

65 U. KRON, "Kultmahle im Heraion von Samos archaischer Zeit. Versuch einer Rekonstruktion”, in R. HÄGG et al. (eds.), Early Greek Cult Practice. Proceedings of the Fifth International Symposium at the Swedish Institute at Athens, 26-29 June, 1986, Stockholm, 1988, p. 144-147.

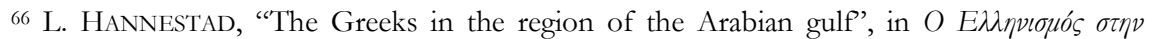

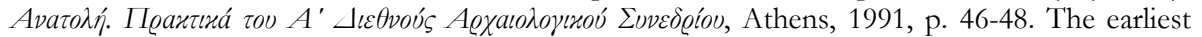
pottery seems to date between 285 and 250 BC, cf. ead., The Hellenistic Pottery from Failaka, Aarhus, 1983 (Ikaros. The Hellenistic Settlements, 2:1), p. 75-78.

${ }^{67}$ K. Jeppesen, The Sacred Enclosure in the Early Hellenstic Period, Aarhus, 1989 (Ikaros. The Hellenistic Settlements, 3), p. 72 f. assumes that temple A was founded around 260 BC, while temple $\mathrm{B}$ was built some years later, perhaps around $240 \mathrm{BC}$.

68 JEPPESEN, o.c. (n. 67), p. 53-67. 
divine owner of the sanctuary as Artemis (Fig. 7). It seems that the temple was founded during the rule of Antiochos III at the very beginning of the second century BC. ${ }^{69}$

Fig. 7

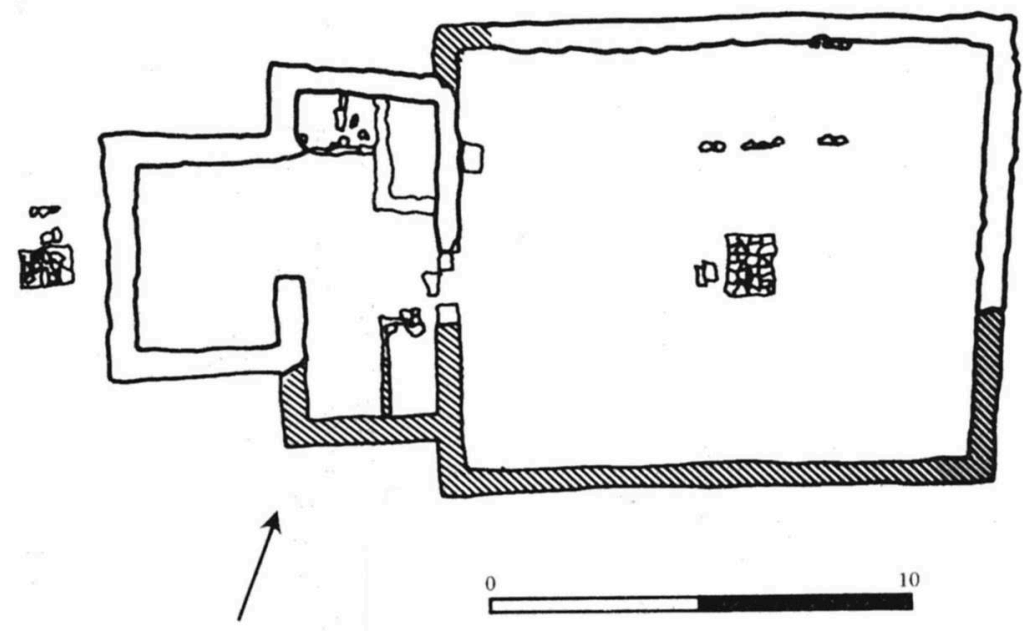

Two important, but nonetheless problematic epigraphic finds refer to religious aspects concerning the temples of Soter and Soteira, most probably those of Zeus and Artemis. The older one is a dedication of Soteles an Athenian (or Soteles and Athenaios or Soteles son of Athenaios) and other soldiers to Zeus Soter, Poseidon and Artemis Soteira. The exact dating of the inscription cannot be determined: The fourth and the early third century are the most often suggested datings. This makes three interpretations possible: Greek cults were implanted on the island either through mercenaries of the Achaemenid emperors or through soldiers of Alexander the Great, or after colonizing activities of the Seleucid rulers. ${ }^{70}$

${ }^{69}$ A. Caubet, J.-F. SAlLES, "Le sanctuaire hellénistique, B6", in J.-F. SAlles (ed.), Failaka: Fouilles françaises 1983, Lyon 1984, p. 73-156; D.T. POTTS, The Arabian Gulf in Antiquity II: From Alexander the Great to the Coming of Islam, Oxford, 1990, p. 164 f. O. CALLOT, "Failaka à l'époque hellénistique", in T. FAHD (ed.), L'Arabie préislamique et son environnement bistorique et culturel, Leiden, 1989, p. 138 f. emphasises the mixture of Greek and indigenous elements especially in this temple: "ce sanctuaire et son matériel montre clairement la coexistence, tout à fait normale d'ailleurs, d'un élément grec et d'un élément indigène."

${ }^{70}$ For POTTS, o.c. (n. 69), p. 183-186 all three alternative explanations appear possible. Ch. ROUECHE, S.M. SHERWIN-WHITE, "Some Aspects of the Seleucid Empire: the Greek Inscriptions from Failaka, in the Arabian Gulf", Chiron 15 (1985), p. 4-10 exclude the possibility of Greek mercenaries of the Achaemenids on the island, while they are favouring the idea of a dedication that "derives from a Seleucid garrison stationed on Ikaros in the first phase of Seleucid occupation". For the transfer of cults by soldiers, see A. CHANIOTIS, War in the Hellenistic World: A Social and Cultural History, Oxford, 2005, p. 149-153. 
The suggestions about the dating of the second inscription vary between the mid-third and the first half of the second century. In this epigraphic document an unknown Seleucid king demands among other things the transfer of the temple of the Saviour Goddess (Artemis Soteira) into the precinct of the Saviour God (Zeus Soter), a demand that had been ignored at least once in the past. According to D.T. Potts the inscription refers to the transfer of the temple by the sea into the fortress, where the temple of Zeus Soter stood. ${ }^{71} \mathrm{~K}$. Jeppesen suggested, however, that the temple to be transferred has not been excavated yet, and that the new temple of Soteira demanded by the Seleucid king should be identified with temple B. ${ }^{72}$

The archaeological material and the epigraphic evidence attest to the intense presence of Greek elements on the island. The foundation of the temples inside the fortress has an apparent general cultic background (mercenaries or soldiers wished to see their own religious beliefs implanted on the island and in the adequate architectural setting), but the demand of the unknown Seleucid king to transfer the indigenous cult place of Artemis into the Greek enclosure obviously demonstrates a conscious policy to reinforce the Greek elements by means of religion. ${ }^{73}$ An older, pre-Greek cult was to be transferred to a new environment and this automatically implies changes of both the original and the new sacred space. In this case sacred time was also to be changed, since an agon was part of the new arrangement.

The synagogue on Delos presents an example for the creation of sacred space by a religious group desiring to remain exclusive and self-sufficient after its voluntary migration to an alien cultural, religious, and social context. Ikaros, on the other side, is certainly a representative example for a cult transfer due to military expansion accompanied and followed by migration waves. However, in the case of Ikaros we are not dealing with clearly defined, closed religious groups, and the attempts to mix indigenous and Greek religious elements are an

71 RouechÉ - SHERWIN-White, l.c. (n. 70), p. 13-39; POTTs, o.c. (n. 69), p. 186-193. In a stimulating article, B. Borg demonstrates that at least in the case of the Attic temples transferred as a whole or partially to the Agora of Athens in the Augustan era the reasons for this action were definitely not of religious, but rather of practical nature, $c f$. B. BORG, "Athenian Identity changed or preserved?”, in Th. A. SCHMITZ, N. WIATER (eds.), The Struggle for Identity: Greeks and their Past in the First Century BCE (forthcoming). I would like to thank B. Borg for giving me the opportunity to read her unpublished manuscript. On the contrary S. Alcock, Archaeologies of the Greek Past. Landscape, Monuments, and Memories, Cambridge, 2002, p. 54-58 argues in favour of the "symbolic strength" of such itinerant buildings.

72 JEPPESEN, o.c. (n. 67), p. 73.

73 In the most recent study of the inscription, M.-Z. PETropoulou, "A Seleucid Settlement on Failaka", EA 39 (2006), p. 139-147 convincingly reconstructs a royal project to incorporate the Greeks in the native environment and the indigenous cult in the Greek culture. Bringing the pre-Greek cult into the Greek fortress was part of this plan. On the contrary, POTTS, o.c. (n. 69), p. 192 suggested that the temple of the Saviour Goddess, which he identifies with the building by the seashore, was transferred because it was endangered by the sea waves. 
obvious demonstration of that. But what happens, if individuals or groups are forced to migrate, in some cases due to religiously motivated tensions? The erection of a Jewish temple in Ptolemaic Egypt in the first half of the second century $\mathrm{BC}$ is an interesting case for the transfer of rituals and partially of concepts of sacred space because of tensions, banishment, and rivalry. Shortly after $162 \mathrm{BC}$, a Jewish temple was built in Leontopolis, ${ }^{74}$ which was destroyed some time after the destruction of the temple in Jerusalem by Titus. Onias, the exiled son of the high priest Onias, had asked for permission to do so, and Ptolemaios VI not only allowed the erection of the temple, but also granted the land needed in the nome of Heliopolis. According to the literary tradition Onias' temple "was rather to rival the Jews at Jerusalem, against whom he harboured resentment for his exile, and he hoped by erecting this temple to attract the multitude away from them to it."'75

No archaeological remains have been traced so far, and our main literary source, Flavius Josephus, delivers invaluable, but nonetheless contradictory information about the appearance of the temple. In his Jewish Antiquities, Josephus stresses at least twice that the temple in Leontopolis was built in dependence on the temple in Jerusalem: "and being treated with honour by him and his wife Cleopatra, he received a place in the nome of Heliopolis, where he built a temple similar to that in Jerusalem" "wherefore I beg you to permit me to cleanse this temple, which belongs to no one and is in ruins, and to build a temple to the Most High God in the likeness of that at Jerusalem and with the same dimensions." 76 But in the most detailed description of the Leontopolitan temple in his work on the Jewish war, Josephus states exactly the opposite: "Here Onias erected a fortress and built his temple, which was not like that in Jerusalem, but resembled a tower of huge stones and sixty cubits in altitude. The altar, however, he designed on the model of that in the home country, and adorned the building with similar offerings, the fashion of the lampstand excepted for, instead of making a stand, he had a lamp wrought of gold which shed a brilliant light and was suspended by a golden chain. The sacred precincts were wholly surrounded by a wall of baked brick, the doorways being of stone." ${ }^{77}$ It seems more probable that the temple in Leontopolis had some

${ }^{74}$ Fl. Joseph., Bellum Iudaicum VII, 434-436.

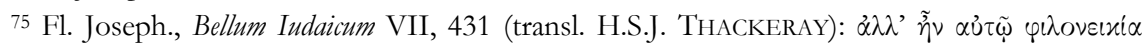

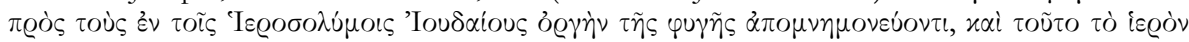

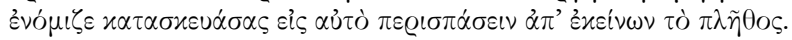

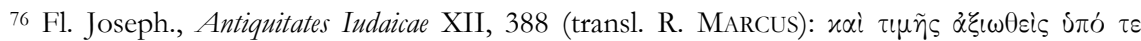

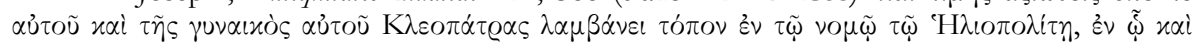

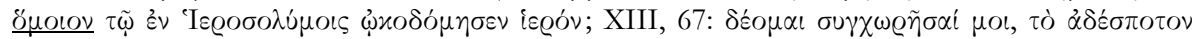

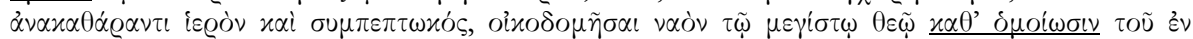

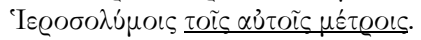

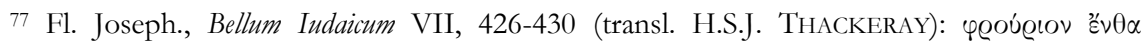

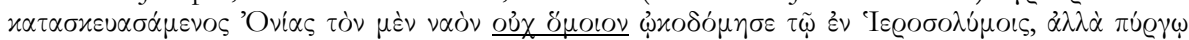

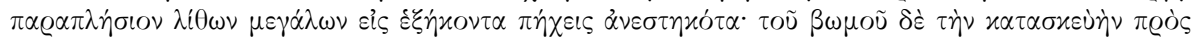


architectural similarities to the temple in Jerusalem, but in its overall spatial design must have been quite independent. However, in one very significant detail Onias consciously orientated himself towards Jerusalem: the altar. Apparently, the altar, the most important architectural part in the ritual spatial organisation of the Leontopolitan temple had indeed to copy ( $\varepsilon \xi \varepsilon \mu \mu \eta \dot{\eta} \sigma \alpha \tau o)$ the one standing in Jerusalem, since there were no innovations or alterations of the sacrificial rituals in the temple of Leontopolis. ${ }^{78}$

\section{Centre and periphery - The creation of bonds by means of sacred architecture}

Fig. 8

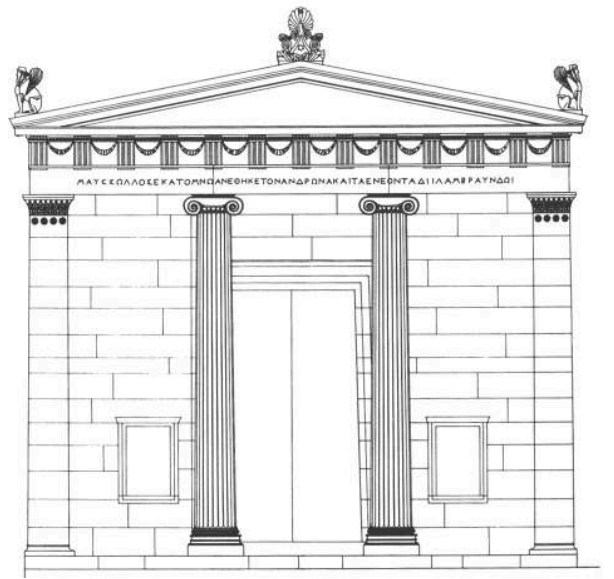

During the fourth century BC dedications of temples in sanctuaries became rare, ${ }^{79}$ and yet it is exactly in this period that the Karian sanctuary of Zeus at Labraunda experienced an unprecedented and extravagant building activity financed by the dynastic house of Halikarnassos. Until the last quarter of the fourth century the sanctuary apparently consisted only of a sacred grove and an altar. ${ }^{80}$ Between 377 and 352 BC, under Mausolos, Andron B, a lavish banqueting house with a marble facade in a mixed style (Ionic columns with a Doric entablature), was erected. With a dedicatory inscription in Greek on the

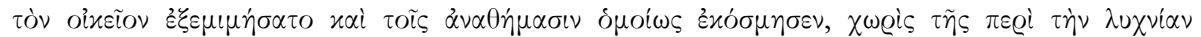

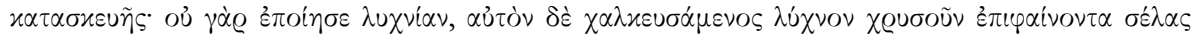

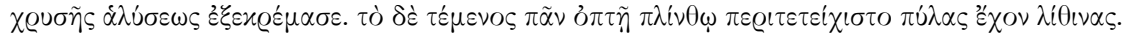

78 A. Kasher, 'Synagogues as 'Houses of Prayer' and 'Holy Places' in the Jewish Communities of Hellenistic and Roman Egypt", in Urman - FleSHER, o.c. (n. 55), p. 207, n. 7. A. FitzPAtricK-MCKinley, "Synagogue Communities in the Graeco-Roman Cities", in J.R. BARTLETT (ed.), Jews in the Hellenistic and Roman cities, London, 2002, p. 74 n. 126, states that Jewish temples such as those in Elephantine or Leontopolis are expressions of alternative Jewish identities, in the case of Leontopolis born out of rivalry. The rivalry between Leontopolis and Jerusalem was, however, related to aspects of primacy, and not of ritual practice, since the sacrifices and the altar's design were in both temples identical.

${ }^{79}$ Konon's foundation of a sanctuary for Aphrodite at Piraeus, Alexander's dedication of the Olympieion in Sardeis, and his involvement in financing the temple of Athena in Priene are the three historically attested examples. The foundation of an Artemis Ephesia sanctuary in Skillous by Xenophon is indeed a special case, since it takes place in Xenophon's private property.

80 P. Hellström, “The Architectural Layout of Hecatomnid Labraunda”, RA (1991), p. $297-$ 308. The existence of an archaic temple is a much-debated matter, which cannot be considered in the present study. 
architrave, the proud benefactor immortalised his action (Fig. 8). A stoa and the temple - the latter remained, however, unfinished - completed the programme of Mausolos. His brother and successor, Idrieus, continued the building programme between 351 and $344 \mathrm{BC}$. The temple received its peristasis and a second banqueting house, Andron A, was erected, resembling in style, material used, and even dedicatory inscription Andron B. ${ }^{81}$ With the erection of two further oikoi and a propylon, the sanctuary of Zeus acquired an overall Greek appearance. Within four decades the Karian dynastic house had transformed a local sacred place into an important sanctuary with a Greek outlook. ${ }^{82}$ The desire for a Greek cultural identity was expressed in a religious context by means of architecture and language in the prominently positioned dedicatory inscriptions. Because of the similar zigzag approach from the propylon to the temple, P. Hellström went as far as to express the intriguing hypothesis that the Hekatomnids had the "ambitions to create a new Delphi in a new Hecatomnid East-Greek empire," - a hypothesis, which is, however, impossible to prove..$^{83}$

Fig. 9

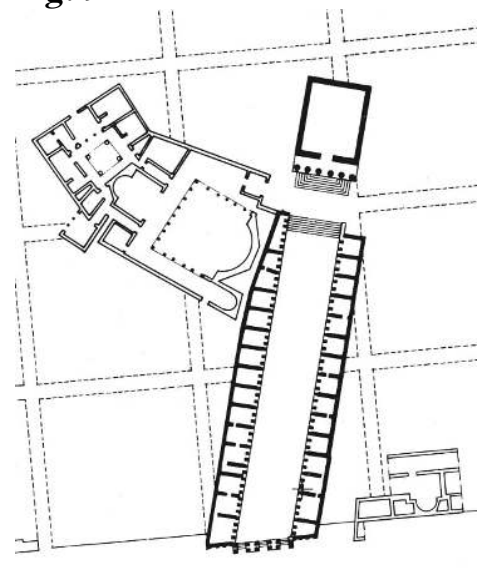

The wish to create virtual bonds between a cultural and/or political centre and a city in the periphery using religious architecture was fulfilled in a more subtle way by the Aphrodisians. In 1979 a large sanctuary complex was excavated in the Karian city of Aphrodite. The dedicatory inscriptions inform us that it was erected in honour of Aphrodite, the Theoi Sebastoi and the Demos. The complex consists of a propylon, two long and extremely elaborated porticoes, and a podium temple (Fig. 9). Construction most probably started under Tiberius and was completed under Nero. A major re-building took place under Claudius, as stated in an inscription. ${ }^{84}$ The complex has an east-west orientation. One entered at the West end through the aforementioned propylon and stood on a very long and very narrow paved area, flanked by tall three-storeyed porticoes lavishly decorated with large relief panels in the upper two storeys. At the East end of the

81 P. Hellström, "The Andrones at Labraynda. Dining Halls for Protohellenistic Kings", in W. Hoepfner, G. Brands (eds.), Basileia. Die Paläste der hellenistischen Könige, Mainz, 1996, p. 164169.

82 P. Hellström, "Hecatomnid Display of Power at the Labraynda Sanctuary", in P. HeLLStröm, B. Alroth (eds.), Religion and Power in the Ancient Greek World, Proceedings of the Uppsala Symposium 1993, Boreas 24, Uppsala, 1996, p. 133-138.

83 Hellström, l.c. (n. 78), p. 308.

${ }^{84}$ K. ERim, Aphrodisias, New York, 1986, p. 106-123. 
complex the temple for the imperial cult was set up on a terrace. R.R.R. Smith demonstrated that the layout, not the architectural details, of the Aphrodisian Sebasteion is reminiscent of the two imperial fora that existed at the time in Rome, the Forum Iulium and the Forum Augusti. The complex at Aphrodisias is in terms of its concept even closer to the Forum Iulium in the separate placing of the temple at the end of the colonnades. ${ }^{85}$ The Sebasteion seems to have been a part of a conscious attempt of the Aphrodisians to demonstrate their tight links to Rome and especially to the Julian family. Despite the Hellenistic forerunners in Asia Minor, the worship of a sovereign must have been new to the city of Aphrodisias.

The Aphrodisian Sebasteion is an exquisite example for both adapting architectural models from the capital of the Roman Empire and at the same time creating an entirely new concept of the sacred space. The city apparently used Roman imperial models, while simultaneously introducing innovative details. After establishing the cult of the Theoi Sebastoi, the Aphrodisians had to create a totally new architectural setting. The solution found is ingenious: A structure reminiscent of the imperial fora, but without slavishly copying them, concentrated totally on the cult of the emperor, since every conceptual detail served the intensification of the aesthetic effect of the imperial temple. The whole complex with its three storeyed colonnades, its extremely narrow paved area, and the temple elevated reminds us of the cella of a Greek temple with a temple instead of a cult statue at the end of the 'cella'. In this ingenious way the city could demonstrate its affiliation to the Julian family. ${ }^{86}$

\section{Conclusions}

The examples for the transmission, adjustment, or even radical change of religious architectural settings that were presented are only a very small selection of evidence provided by the archaeological and textual sources for a phenomenon, which I would like to subsume under the term 'dynamics of ritual space'. ${ }^{87}$ Examples have been intentionally selected, which indeed appear

85 R.R.R. SMITH, "The Imperial Reliefs from the Sebasteion at Aphrodisias", JRS 77 (1987), p. 92-95; Chr. RATTÉ, "New Research on the Urban Development of Aphrodisias in Late Antiquity", in D. PARISH (ed.), Urbanism in Western Asia Minor, Portsmouth, 2001 (JRA, Suppl. 45), p. 121: "it [the Sebasteion] is in fact more purely Italian than any other building complex at Aphrodisias." See also ALCOCK, o.c. (n. 71), p. 90-93 with a strong focus on the imagery of the relief decoration and not on the architectural design of the Sebasteion.

${ }^{86}$ An imitatio of the Forum Augusti - at least as regards the sculptural programme - also existed in the Colonia Augusta Emerita, see S. PANZRAM, Stadtbild und Elite: Tarraco, Corduba and Augusta Emerita zwischen Republik und Spätantike, Stuttgart, 2002 (Historia Einzelschriften, 161), p. 246-251.

${ }^{87} \mathrm{Chr}$. Auffarth, "Sind heilige Stätten transportabel? Axis mundi und soziales Gedächtnis", in A. Michaels (ed.), Noch eine Chance für die Religionsphänomenologie?, Bern, 2001, p. 235-257 poses 
to have very little in common, except for the fact that each one of them illuminates a different aspect of this very complex phenomenon.

The brutal interruption of the ritual tradition at the altar of the temple in Jerusalem was the only case, in which violence played such an eminent role in the transformation of ritual practices and sacred space. The antagonism between the Christian and the pagan religious systems in late Antiquity, which marked the beginning of the transformation of innumerous temples into churches, belongs, of course, to the same category. All other cases presented in this study, deal with more or less peaceful developments, which are due either to internal changes or external influences. The transitory ritual at the sanctuary of Artemis Orthia at Sparta, the sacrifice to Artemis Laphria at Patrai, the cult of Palaimon at Isthmia, and the last phase in the architectural development of the sanctuary of Demeter and Kore at Corinth are all connected with internal changes of existing cults (Orthia, Palaimon, Demeter and Kore), rituals (Laphria), and sacred places (all cases) intensified through an external influence, the dynamic communication between the Greek and Roman conceptions of religion and especially of ritual practice. In the case of the sanctuary of Artemis Orthia at Sparta, for example, the transformation of Spartan society did not lead to the disappearance of an old ritual, but to a change or broadening of its functional spectrum. The flagellation of the youths was not any more basically one of the elements that constituted a local Spartan identity, but became also a spectacle and an agon for others to watch, and this again required a change of the setting. A similar observation can be made about the other examples, for in no case are we confronted with the total abandonment of a cult or a specific ritual practice. On the contrary, we observe dynamic adjustments of well established, pre-existing cults and rituals to new needs, new ethnic identities, and new concepts of how religion should and could be practiced.

Both the copying in Athens of an Epidaurian architectural concept, which reflected Asklepios' duality as a god and a hero, and the reproduction of the Nilotic landscape in cult places of Egyptian deities are connected to important aspects such as the interdependences of cult practice, physical environment and mythological topography (i.e. the importance of the Nile for the Egyptian cults, the dual character of Asklepios). Not only the cult of the Egyptian deities, but also that of Asklepios are alien forms of cult practice in a new environment. This statement is obvious as regards the cult of the Egyptian deities in a Greek cultural context, but it also applies to the cult of Asklepios, which ultimately overshadowed some of the earlier indigenous healing cults in Athens. It is selfevident that the Epidaurian Asklepios needed some adjustments before he became an 'Athenian', without ever loosing his original character, for his main festival, the Epidauria, always reminded the Athenians of the origin of their

quite similar questions, but concentrates on Mircea Eliade's theoretical models and their validity in the contemporary phenomenology of religion. 
new god. Although we are not dealing with the invention of a new cult like, for example, in the case of Glykon and its 'creation' by Alexander, the introduction of Asklepios to Athens or of Sarapis to Delos are tightly connected to individuals, who brought foreign cults to their new environment and certainly played an important role in the transmission of the adequate spatial concepts of the original cults.

The well studied, but also very complex phenomenon of the Diaspora synagogues brought us to a different form of interdependence between ritual and space. In the case of the Jewish (or Samaritan) communities, closed religious groups conceived sacred places that fulfilled the essential religious need for gathering. The architectural form was neither a private house nor a religious association's place, but something new, reminiscent of both aforementioned architectural types, and yet at the same quite distinct. The particularity of the synagogues as regards the phenomenon considered in this article is that they are not trying to transfer the architectural or, even more general, spatial concept of the temple of Jerusalem in a new environment. The religious needs are decisive in the creation of the synagogues and not their architectural interdependence with the temple in Jerusalem. Water facilities appear to be an essential element of a synagogue, and in this respect synagogues at least superficially present similarities to the sanctuaries of the Egyptian deities. And yet, water in the sanctuaries of Egyptian deities represents the river Nile, thus, it is the quintessential part of the spatial and religious structure of a sacred place. In synagogues, water is important, too, but more as a means to achieve the physical purity needed for religious purposes.

Compared to the synagogues and their architectural disassociation from the temple in Jerusalem, the creation of a Jewish temple in Leontopolis presents the other end of this line: a sacred place created partially in conscious dependence on the temple of Jerusalem and at the same as its rival. The altar in Leontopolis was a copy of the one in Jerusalem, thus religious architectural form became an important means in the battle over religious authority. It is remarkable that after the destruction of the temple in Jerusalem by Titus, the temple in Leontopolis had to be closed, for it was also considered a trouble spot of significant potential.

Naukratis is a particularly interesting example for the transfer not only of cults and ritual practices in general, but also for the importance of cult instruments and further paraphernalia that were imported to Naukratis from the mother-cities to be used in the relevant cults of the Greek city at the Nile's delta. Whether the ritual space in the Naukratian sanctuaries was structured according to that in the respective sanctuaries of the mother-cities has to remain for the time being unanswered. The transformation of the religious landscape of ancient Ikaros in the Arabian Gulf demonstrates the importance of a particular form of mobility for the introduction of rituals and their 
adequate architectural form into a different region: the mobility of soldiers. Furthermore, Ikaros is in a later moment of its historical development an example for a peacefully forced mixture of new and indigenous cultural and religious elements by a Hellenistic ruler, who apparently used religion and religious architecture as a means to create relative homogeneity; in a certain way this was what Antiochos IV tried to accomplish, but aiming at a homogeneity based on the religious traditions of a single culture, his own.

Finally, the architectural Greekness of the sanctuary of Zeus at Labraunda and the indirect imitation of a most central element of Roman topography (Forum Iulium) by the planers of the Sebasteion at Aphrodisias in a subtle way express the particular symbolic interconnection between sacral architecture and the attempt to create cultural and political bonds. In my view, especially the Aphrodisian Sebasteion goes even further by creating a virtual open space cella with the temple for the imperial cult in place of the cult statue.

Violent interaction, social transformation, peaceful cultural communication, migrational waves, the introduction of new cults, the mobility of ethnic and religious groups, ideological and political factors, and rivalry between cult places are only some of the parameters that one needs to take into account, when studying the dynamic relation between rituals and their architectural and geographical setting. A sacred space continuously used between the eleventh century $\mathrm{BC}$ and the fourth century $\mathrm{AD}$ (e.g. Isthmia) does not by all means presuppose the same cult, the same ritual practices, or even the same architectural design for this whole vast period of time. The assumption of continuity in ritual practice is increasingly considered an illusion. But also the concept of a fixed and unchanged sacred space can be proven to be a methodological and interpretive pitfall. ${ }^{88}$ Sacred space, in general, is an anthropogenic concept and a socio-cultural construct. Despite the conservative nature of religious practices, the mortals responsible for administration and cult in Greek sanctuaries sensitively reacted to changes occurring in the religious, social, political, and cultural context, dynamically adjusting the architectural outlook of sanctuaries to the development of ritual practices.

Joannis MYLONOPOULOS

Department of Art History and Archaeology

Columbia University

826 Schermerhorm Hall (MC 5517)

1190 Amsterdam Ave.

NEW YORK, NY 10027

Email:jm3193@columbia.edu

88 One of the most often recurring interpretive pitfalls appears to be the assumption that Christian churches represent a continuity in the use of sacred space, see for example W. Burkert, Greek Religion. Archaic and Classical, Oxford, 1985, p. 84: "even Christians followed tradition, erecting chapels in place of sanctuaries or transforming temples into churches." See, however, CHANIOTIS, l.c. (n. 4), p. 147. 


\section{List of illustrations}

Fig. 1: after N. BOOKIDIS, R.S STROUD, Corinth XVIII, 3: The Sanctuary of Demeter and Kore. Topography and Architecture, Princeton, 1997, plan 6.

Fig. 2: after E. GEBHARD et al., "University of Chicago Excavations at Isthmia, 1989: III”, Hesperia 67 (1998), p. 419, Fig. 8.

Fig. 3: after J. RieTHMÜLLER, Asklepios. Heiligtümer und Kulte, vol. I, Heidelberg, 2005, p. 253 , Fig. 36.

Fig. 4: after W. RADT, Pergamon. Geschichte und Bauten einer antiken Metropole, Darmstadt, 1999, p. 202, Fig. 144.

Fig. 5: after M. TRÜMPER, "The Oldest Original Synagogue Building in the Diaspora. The Delos Synagogue Reconsidered", Hesperia 73 (2004), p. 566, Fig. 38a.

Fig. 6: after K. JEPPESEN, The Sacred Enclosure in the Early Hellenstic Period, Aarhus, 1989 (Ikaros. The Hellenistic Settlements, 3), p. 30, Fig. 33.

Fig. 7: after D.T. POTTS, The Arabian Gulf in Antiquity II: From Alexander the Great to the Coming of Islam, Oxford, 1990, p. 159, Fig. 10.

Fig. 8: after P. HeLlSTRÖM, "Hecatomnid Display of Power at the Labraynda Sanctuary", in P. Hellström, B. Alroth (eds), Religion and Power in the Ancient Greek World, Proceedings of the Uppsala Symposium 1993, Uppsala, 1996 (Boreas, 24), p. 137, Fig. 2.

Fig. 9: after R.R.R. SMITH, Chr. RATTÉ, "Archaeological Research at Aphrodisias in Caria, 1997 and 1998”, AJA 104 (2000), pl. II (between p. 228 and 229). 